University of Miami Law School University of Miami School of Law Institutional Repository

1993

\title{
Property and Pragmatism: A Critique of Radin's Theory of Property and Personhood
}

Stephen J. Schnably

University of Miami School of Law, schnably@law.miami.edu

Follow this and additional works at: https://repository.law.miami.edu/fac_articles

Part of the Law and Politics Commons, and the Public Law and Legal Theory Commons

\section{Recommended Citation}

Stephen J. Schnably, Property and Pragmatism: A Critique of Radin's Theory of Property and Personhood, 45 Stan. L. Rev. 347 (1993).

This Article is brought to you for free and open access by the Faculty and Deans at University of Miami School of Law Institutional Repository. It has been accepted for inclusion in Articles by an authorized administrator of University of Miami School of Law Institutional Repository. For more information, please contact library@law.miami.edu. 


\title{
Property and Pragmatism: A Critique of Radin's Theory of Property and Personhood
}

\author{
Stephen J. Schnably*
}

I. INTRODUCTION $\ldots \ldots \ldots \ldots \ldots \ldots \ldots \ldots \ldots \ldots \ldots \ldots \ldots \ldots \ldots \ldots \ldots \ldots \ldots, \quad 347$

II. Radin's Theory of Property and Personhood ......... 354

III. Personhood as an ARena of Power AND Resistance ... 361

A. The Appeal to Consensus ....................... 362

1. The nonexistence of consensus.................. 363

2. The impossibility of bracketing consensus. ......... 371

3. The first heuristic. ........................ 375

B. Commodification as Absolute Power ................ 379

1. The tendency toward stasis.................... 380

2. Commodification in work and personal life......... 384

3. The second heuristic. ........................ 397

IV. ConClUSION .................................... 404

\section{INTRODUCTION}

Recent years have seen the emergence of pragmatism as a central focus of legal theory. ${ }^{1}$ Although pragmatism is an elusive term at best, part of its attraction may lie in its potential to provide a moderate response to two strands of contemporary legal theory: the indeterminacy critique and the critique of grand theory. The indeterminacy critique, associated with the critical legal studies school, has carried on the legal realists' attack on formalism. ${ }^{2}$ One reaction to this critique has been the effort to formulate a

* Associate Professor of Law, University of Miami. A.B., Harvard College, 1976; J.D., Harvard Law School, 1981. I am grateful to David Abraham, Tony Alfieri, Wes Daniels, Marc Fajer, Michael Fischl, Pat Gudridge, Lisa Iglesias, Jenni Jaff, Jim Kainen, Lili Levi, Martha Mahoney, Jeremy Paul, Rob Rosen, and Steve Winter for their comments and criticisms. I owe particular appreciation to Peggy Radin for the inspiration of her work and the generousness of her response to my critique. Tucker Ronzetti served as a perceptive critic and research assistant in the early stages of the project, and Alberto Zapata and Adam Moskowitz provided excellent research assistance in its later stages.

1. See, e.g., Steven D. Smith, The Pursuit of Pragmatism, 100 Yale L.J. 409 (1990); Symposium on the Renaissance of Pragmatism in American Legal Thought, 63 S. CAL. L. REV. 1569 (1990).

2. For examples of the indeterminacy critique, see MARK KelmaN, A Guide to Critical Legal Studies 45-51 (1987); James Boyle, The Politics of Reason: Critical Legal Theory and Local Social Thought, 133 U. PA. L. REv. 685 (1985); Gary Peller, The Metaphysics of American Law, 73 
middle ground, acknowledging the critique of formalism while still maintaining some sense of the separation of law and politics upon which the liberal notion of the rule of law depends. Pragmatism may seem to occupy that middle ground insofar as it implies a recognition that legal rules are "contingent not just upon the acts of legislatures or other authoritative entities, but also upon the surrounding social context, the content of an entire form of life." 3

The second strand questions the proper scope of legal theory; significant elements of the legal academy increasingly have turned away from grand theorizing in any form, focusing instead on context, experience, and plurality. For example, important currents of feminist thought reject grand theories and instead emphasize the role of narrative and the concrete. ${ }^{4}$ Critical race theorists join this critique by emphasizing the perspective and experience of the oppressed. ${ }^{5}$ The turn to pragmatism in legal theory accords well with this shift; though used in different ways by different theorists, "pragmatism" suggests, if nothing else, a focus on context and practice, as well as a drawing back from grand theory. ${ }^{6}$

Margaret Jane Radin's work on property and personhood represents a fruitful encounter between these two diverse trends. In two important respects her theory constitutes a continuing effort to develop a self-consciously pragmatic understanding of the law. ${ }^{7}$ First, Radin's efforts appear to be mo-

CAL. L. Rev. 1151 (1985); Joseph William Singer, The Player and the Cards: Nihilism and Legal Theory, 94 YALE L.J. 1 (1984). Of course, one cannot give any single characterization of the critical legal studies movement. See, e.g., Richard L. Abel, A Critique of Torts, 37 UCLA L. REv. 785, 785 (1990) (self-consciously applying a critical legal studies approach while disclaiming interest in "the indeterminacy of legal rules").

3. Margaret Jane Radin, Reconsidering the Rule of Law, 69 B.U. L. REv. 781, 808 (1989) [hereinafter Radin, Rule of Law]; see also Margaret Jane Radin, The Liberal Conception of Property: Cross Currents in the Jurisprudence of Takings, 88 CoLUM. L. REv. 1667, 1680 (1988) [hereinafter Radin, The Liberal Conception of Property] ("Pragmatism is essentially particularist, essentially context-bound and holistic; each decision is an all-things-considered intuitive veighing. Pragmatism is indeed 'essentially' ad hoc.").

4. See, e.g., Kathryn Abrams, Hearing the Call of Stories, 79 CAL. L. REv. 971 (1991); Martha L. Fineman, Challenging Law, Establishing Differences: The Future of Feminist Legal Scholarship, 42 FLA. L. REv. 25, 28-30 (1990); Mari J. Matsuda, Liberal Jurisprudence and Abstracted Visions of Human Nature: A Feminist Critique of Rawls' Theory of Justice, 16 N.M. L. REv. 613, 618-21 (1986); Ann C. Scales, The Emergence of Feminist Jurisprudence: An Essay, 95 Y ALE L.J. 1373, 1376-80 (1986); cf. Marc A. Fajer, Can Two Real Men Eat Quiche Together?: Storytelling, GenderRole Stereotypes, and Legal Protection for Lesbians and Gay Men, 46 U. MIAMI L. REV. 511 (1992) (feminist analysis of gay rights and narrative). For a more positive evaluation of the role of "grand theory" in feminist theorizing, see Frances Olsen, Feminist Theory in Grand Style, 89 Colum. L. Rev. 1147, $1169-74$ (1989) (reviewing CATHERINE A. MACKinNon, FEMINISM UNMODIFIED: DisCOURSES ON LIFE AND LAW (1987)).

5. See, e.g., Kimberlé Crenshaw, A Black Feminist Critique of Antidiscrimination Law and Politics, in The Politics of LAW: A Progressive Critique 195 (David Kairys ed., rev. ed. 1990); Richard Delgado, When a Story is Just a Story: Does Voice Really Matter?, 76 VA. L. REv. 95 (1990); Mari J. Matsuda, Looking to the Bottom: Critical Legal Studies and Reparations, 22 HARV. C.R.-C.L. L. REV. 323 (1987).

6. See Margaret Jane Radin, Diagnosing the Takings Problem, in COMPENSATORY JUSTICE: Nomos XXXIII, at 248, 270 (John W. Chapman ed., 1991) [hereinafter Radin, Takings] (referring to "the pragmatic practice of situated judgment in light of both partial principles and the unique particularities of each case").

7. Radin, The Liberal Conception of Property, supra note 3, at 1680 (supporting "a pragmatic 
tivated by a desire to explore the limits of rule-like notions of law without fully embracing the erasure of the separation of law and politics. ${ }^{8}$ Second, Radin appears to be motivated by a concern that grand, sweeping theories may blind us to the actual significance and impact of legal rules that are imposed in a "nonideal" world marked by poverty, racism, and sexism." Thus, Radin's theory of property and personhood makes a valuable contribution both to the search for a middle ground between formalism and indeterminacy and to the emerging focus on context and plurality.

Radin's work has rightly been influential and widely cited in a variety of contexts. ${ }^{10}$ Her project is all the more interesting because of the context in which she has pursued it: a critique of law and economics theory for its

approach to decision making"); Margaret Jane Radin, The Pragmatist and the Feminist, 63 S. CAL. L. REv. 1699 (1990) [hereinafter Radin, Pragmatist]; Margaret Jane Radin \& Frank Michelman, Pragmatist and Poststructuralist Critical Legal Practice, 139 U. PA. L. REv. 1019 (1991) [hereinafter Radin \& Michelman, Critical Legal Practice]; see also Radin, Rule of Law, supra note 3, at 801, 81217 (describing pragmatism as concerned with the practice of communities).

8. Thus, Radin has argued:

[W] must relinquish the traditional form of the ideal of the Rule of Law, without thinking that the only alternative is arbitrary political power. We must relinquish the formalist equation and the notion that judges and lawyers merely passively apply all-inclusive preexisting rules, without thinking that the only alternative is unchecked personal discretion.

Margaret Jane Radin, "After the Final No There Comes a Yes": A Law Teacher's Report, 2 YALE J.L. \& HuMAN. 253, 263 (1990) (footnote omitted).

9. See Margaret Jane Radin, Market-Inalienability, 100 HARV. L. REv. 1849, 1915 (1987) [hereinafter Radin, Market-Inalienability] ("[W]e are situated in a nonideal world of ignorance, greed, and violence; of poverty, racism, and sexism. In spite of our ideals, justice under nonideal circumstances, pragmatic justice, consists in choosing the best alternative now available to us."); $c f$. Margaret Jane Radin, Justice and the Market Domain, in MARKETS AND JUSTICE: NoMOS XXXI, at 165, 186 (John W. Chapman \& J. Roland Pennock eds., 1989) [hereinafter Radin, Market Domain] (referring to "non-ideal or second-best (or perhaps just practical) justice").

10. The distinction that Radin draws between personal and fungible property has been applied in many different contexts. See, eg., Silverman v. Barry, 845 F.2d 1072, 1081 (D.C. Cir.) (condominium conversions), cert. denied, 488 U.S. 956 (1988); David L. Rosendorf, Comment, Homelessness and the Uses of Theory: An Analysis of Economic and Personality Theories of Property in the Context of Voting Rights and Squatting Rights, 45 U. MIAMI L. Rev. 701, 709 (1990-1991) (homelessness); Michael H. Schill, Privatizing Federal Low Income Housing Assistance: The Case of Public Housing, 75 CORNELl L. REv. 878, 934 \& n.234 (1990) (public housing); Joseph William Singer, The Reliance Interest in Property, 40 STAN. L. REV. 611, 661-62 (1988) (plant closings). Radin's analysis of commodification and market-inalienability has been widely cited in the context of surrogacy. See, e.g., In re Baby M, 109 N.J. 396, 439-40, 537 A.2d 1227, 1249 (1988); Elizabeth S. Anderson, Is Women's Labor a Commodity?, 19 PhIL. \& PuB. Afr. 71, 71 \& n.1 (1990); Joan Mahoney, An Essay on Surrogacy and Feminist Thought, 16 LAw, MED. \& Health Care 81, 82 n.9, 83 n.21 (1988). It has been cited in a variety of other contexts as well. See, e.g., George M. Armstrong, Jr., The Reification of Celebrity: Persona as Property, 51 LA. L. Rev. 443, 450 n.39, 451 \& n.45 (1991) (celebrity persona); Jody Freeman, The Feminist Debate Over Prostitution Reform: Prostitutes' Rights Groups, Radical Feminists, and the (Im)possibility of Consent, 5 BERKELEY WoMEN's L.J. 75, 101-04 (1989-1990) (prostitution); Karen Gross, The Debtor as Modern Day Peon: A Problem of Unconstitutional Conditions, 65 Notre DAME L. REv. 165, 185 n.133, 197 n.219, 201 n.246 (1990) (bankruptcy law); Michelle Bourianoff Bray, Note, Personalizing Personalty: Toward a Property Right in Human Bodies, 69 TEx. L. REv. 209, 214-19 (1990) (human body); see also JoHN Friedmann, Empowerment: The Politics of Alternative Development 11-12 (1992) (invoking "human flourishing" as a guide to development theory).

Radin's analysis of "double binds" has also been taken up by other commentators. See, e.g., Richard Craswell, Passing on the Costs of Legal Rules: Efficiency and Distribution in Buyer-Seller Relationships, 43 STAN. L. REv. 361, 395-96 \& n.60 (1991) (implied warranties); Andrew Koppel- 
inappropriate use of "market rhetoric."11 Economic analysis of the law ironically shares with the indeterminacy critique a complete rejection of legal formalism and of any distinctive rule-like character of law. It relies on economic analysis, not legal reasoning, as the sole determinant of legal outcomes. ${ }^{12}$ Moreover, the law and economics school seeks to explain and issue prescriptions for virtually every area of the law; it might seem to embrace sweeping theory on a grand scale. Practitioners of law and economics acknowledge no apparent limit to the domain of their analysis, tackling diverse areas of personal and social life like adoption, ${ }^{13}$ prostitution, ${ }^{14}$ and religious freedom. ${ }^{15}$

Radin presents a comprehensive alternative to law and economics theory. As we embody ourselves in the world around us, she argues, some property, which she calls "personal," becomes essential to our personhood. Other property is "fungible," and can be bought and sold without harm to personhood. ${ }^{16}$ To distinguish between these two forms of property, Radin

man, Forced Labor: $A$ Thirteenth Amendment Defense of Abortion, 84 Nw. U. L. REV. 480, 502 \& $\mathrm{n}$. 97 (1990) (abortion rights).

Finally, Radin's writings have been cited or included in property law textbooks. See, e.g., Richard H. Chused, Cases, Materials and Problems in Property 84-89 (1988); Jesse Dukeminier \& James E. Krier, Property 137 (2d ed. 1988); Charles M. HaAR \& Lance Liebman, Property and LaW 63-64 (2d ed. 1985).

11. For other critiques of market rhetoric, see KELMAN, supra note 2, at 114-85; Jeffrey L. Harrison, Egoism, Altruism, and Market Illusions: The Limits of Law and Economics, 33 UCLA L. REv. 1309 (1986); Frank I. Michelman, Ethics, Economics, and the Law of Property, in ETHICs, Economics, AND THE LAw: Nomos XXIV, at 3 (J. Roland Pennock \& John W. Chapman eds., 1982).

12. As Richard Posner has written:

The ultimate test of a rule derived from economic theory is not the elegance or logicality of the derivation but the rule's effect on social wealth. The extension of the rule of capture to oil and gas was subjected to such a test, flunked, and was replaced ... by efficient rules.

The other rules of the common law can and should be tested likewise.

Richard A. Posner, The Problems of Jurisprudence 362 (1990); see also id. at 454 ("[T] he essence of formalism is to conceive of law as a system of relations among ideas rather than as a social practice.").

To be sure, economic analysis could be characterized as formal: It is built on a model of analytical rules with little concern for reality. See Roberto MANGABEIRA UNGER, SOCIAL THEORY: ITS SIrUATION AND ITS TASK 127 (1987) (noting the tendency of mainstream economists to conceive of their discipline exclusively as "an analytical apparatus," resulting in "formal virtuosity" but "substantive sterility"). Nevertheless, economic analysis, unlike legal formalism, denies that there is a distinctively legal mode of reasoning. See, e.g., POSNER, supra, at 459 ("[T]here is no such thing as 'legal reasoning."').

13. See Elisabeth M. Landes \& Richard A. Posner, The Economics of the Baby Shornage, $7 \mathrm{~J}$. LEgal Stud. 323, 347 (1978); cf. GARY S. BECKER, A TREATISE ON THE FAMILY (1981) (analyzing family relations, including marriage and child-rearing, in terms of market relations).

14. See Helen Reynolds, The Economics of Prostitution (1986).

15. See Michael W. McConnell \& Richard A. Posner, An Economic Approach to Issues of Religious Freedom, 56 U. CHI. L. REv. 1 (1989); cf. Corry Azzi \& Ronald Ehrenberg, Household Allocation of Time and Church Attendance, 83 J. PoL. EcoN. 27 (1975) (analyzing church attendance as trade-off between opportunity cost of time and "afterlife benefits").

16. See Margaret Jane Radin, Property and Personhood, 34 STAN. L. REv. 957, 959-60, 986-87 (1982) [hereinafter Radin, Personhood]. Radin suggests that "consensus must be a sufficient source of objective moral criteria" to distinguish personal from fungible property. Id. at 969; see also Radin, Market-Inalienability, supra note 9, at 1908 ("There is no algorithm or abstract formula to tell us which items are (justifiably) personal. A moral judgment is required in each case."). 
appeals to a normative vision of human flourishing. This vision is in a sense pragmatically conceived, drawing on particular values that are said to be shared or are implicit in our society, rather than on some transcendent, abstract theory of what is right. ${ }^{17}$ The distinction between the two types of property matters, Radin argues, because we generally should accord personal property greater protection than fungible property. ${ }^{18}$ We may even want to prevent personal property or personal attributes from being treated as fungible goods by making them "market-inalienable"-that is, by forbidding their purchase and sale. ${ }^{19}$

There is much to be said for Radin's project, both in its critical and constructive aims. Her work bolsters a number of progressive reforms, such as rent control statutes, against the onslaught of conservative law and economics critiques. ${ }^{20} \mathrm{Her}$ analysis of commodification points out the harm created by the relentless application of market rhetoric to all areas of social and personal life. ${ }^{21}$ More generally, Radin's work suggests that a relatively determinate meaning can be attached to rules by careful examination of the social practices that form their context. This suggestion forms a thoughtful response to the indeterminacy critique, which, taken to extremes, implies the insufficiency of language for any communication. ${ }^{22}$ By grounding the possibility of meaning in actual social life, Radin raises the possibility of a theory of rules and language that avoids that absurd result without calling upon formalist conceptions. She consciously aims to construct a progressive theory that overcomes the distinction between subject and object, ${ }^{23}$ and bridges

17. For example, Radin asserts our society currently values embodiment in the home. Radin, Personhood, supra note 16, at 987 ("There is both a positive sense that people are bound up with their homes and a normative sense that this is not fetishistic."); Radin, Market-Inalienability, supra note 9, at 1908; Radin, Takings, supra note 6, at 257, 259. However, she does not claim that such embodiment represents some universal, timeless value.

18. Radin, Personhood, supra note 16, at 986 ("The more closely connected with personhood, the stronger the entitlement" to protection of the property right.); Radin, Takings, supra note 6, at $259-60$ (suggesting that personal property should have greater protection against eminent domain than does fungible property).

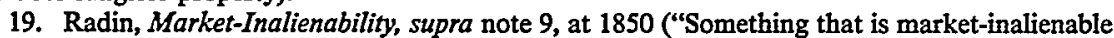
is not to be sold, which in our economic system means it is not to be traded in the market."). Examples would include the prohibition of selling one's baby or organs.

20. Radin argues that residential tenants have a different and more "personal" kind of interest in the apartments in which they live than does a landlord who views the apartment building primarily as a "fungible" investment. Radin, Personhood, supra note 16, at 960, 992-96; Radin, MarketInalienability, supra note 9, at 1878; Margaret Jane Radin, Residential Rent Control, 15 PHIL. \& PUB. AfF. 350, 360 (1986) [hereinafter Radin, Rent Control].

21. See Radin, Market Domain, supra note 9, at 190 ("[1n some cases market rhetoric itself can be viewed as an act injurious to personhood."); Radin, Market-Inalienability, supra note 9, at 1885 ("[U]niversal market rhetoric does violence to our conception of human flourishing."); id. at 1859-70, $1877-87$.

22. Cf. Steven L. Winter, Transcendental Nonsense, Metaphorical Reasoning, and the Cognitive Stakes for Law, 137 U. PA. L. REV. 1105, 1110-11 (1989) ("Part of what is troubling about the subjectivist approach to law is that it assumes that we have more trouble communicating than we actually do.").

23. See Radin, Rent Control, supra note 20, at 363 (her theory of personhood "blurs or bridges the subject/object dichotomy"); Radin, Market-Inalienability, supra note 9, at 1909 ("I am suggesting that we relinquish the subject/object dichotomy and rely instead on our best moral judgment in light of the best conception of personhood as we now understand it."). 
the gap between revolutionary transformation and preservation of the status quo. ${ }^{24}$

While Radin's project is worthy, her work is bound to fall prey to an implicit conservative bias if carried out in its present form. ${ }^{25}$ The ramifications of this criticism extend well beyond Radin's own attempt to develop a theory of property and personhood. For Radin's work reveals a characteristic common to much contemporary legal theorizing: a politics informed by an instinct for consensus and an aversion to conflict. A critique of her work will therefore have broad significance, constructive as well as critical. ${ }^{26}$

A primary problem with Radin's analysis is that it both hides and glorifies power. Running throughout Radin's analysis is a treatment of power that at once hides it and glorifies it. In one sense, Radin's methodology keeps power hidden from view by appealing to social consensus as a source of normative guidance for the law. This appeal permits legal issues to be bracketed or separated out from deeply controversial disputes about what people are and should be like. The appeal to consensus-not to some general, overarching consensus, but to particular instances of values currently shared-is explicit in her early work, and carries over into her conception both of "human flourishing" and of the rule of law. ${ }^{27}$ Although Radin recognizes the existence of conflict and disagreement in society, she assumes that legal practices can only be relatively determinate or rule-like if they are grounded upon deep social consensus: "Some practices are so deeply accepted that they seem like immutable rules."28

It is the very attempt to appeal to consensus, however, that I question. After setting out a more detailed account of Radin's work in Part II, I will

24. See Radin, Market-Inalienability, supra note 9, at 1875-77 (comparing "evolutionary" and "revolutionary" approaches to noncommodification).

25. Before any criticism is offered, it is legitimate to ask whether a variety of works written over a period of more than a decade can fairly be analyzed as a whole, particularly when they have not been consciously offered as part of a single, ongoing project. In Radin's case, I believe that they can. My critique does not suggest that her work is internally inconsistent-a charge that vould be vulnerable to the simple reply that Radin's thought has evolved over time. Rather, my critique shows that Radin's work on property and commodification is informed, with a relatively high degree of constancy, by conceptions of the nature of law and legal argument that she shares with most of the legal academy.

26. Thus, I undertake the critique in roughly the same spirit as that which informs Unger's critique of modern social theory. See UNGER, supra note 12, at 143 (arguing that because "no hardand-fast distinction separates criticism and construction," the "disintegration of the available traditions of social thought is no mere entropic process: the disintegrating traditions have forged many of the instruments required for their transformation"). To criticize Radin's work is to think about how legal theory might be recast.

27. But see Margaret Jane Radin, Lacking a Transformative Social Theory: A Response, 45 STAN. L. REv. 409, 415 n.25 (noting that Radin has "deliberately not used the word 'consensus' since 1982). The particular judgment that Radin makes about embodiment in the home, for example, seems to be the same in substance and character whether offered as an example of consensus or of an ideal of human flourishing. Compare Radin, Personhood, supra note 16, at 969, 987 (noting social consensus that "people are bound up with their homes and ... that this is not fetishistic") with Radin, Market-Inalienability, supra note 9, at 1908 ("What makes identifying oneself with something justifiable ... is an appropriate connection to our conception of human flourishing. . . . An example of a justifiable kind of relationship is people's involvement with their homes.").

28. Radin, Rule of Law, supra note 3, at 819. 
argue in Part III that the law can never simply implement some consensus regarding property and personhood. The social constitution of personhood is always at stake when issues of property and commodification are decided. A theory that brackets moral issues from legal ones overlooks the manner in which exercises of power help shape the consensual norm that is supposedly being taken as a guide. To avoid that circularity, legal theorists must focus on the conflict that can always be found beneath the surface of apparent consensus.

While Radin's methodology obscures the exercise of power, it also, paradoxically, tends to treat power as irresistible. Radin's identification of commodification with the system of legal rules governing market transfer effectively precludes an understanding of the possibility of resistance to the forces that promote commodification. If market-alienability is fully permitted, in her view, then we are fully commodified; if market-inalienability is permitted to a limited extent, then we are partially commodified. For Radin, the only way to counter commodification is to change the legal rules governing property and its transfer, making market-inalienable what was market-alienable. Once we take that approach, decommodification inevitably involves the imposition of a disability-that is, stripping someone of the legal right to make a market transfer of an object or an aspect of herself. ${ }^{29}$

In contrast, I will argue in Part III that while commodification presupposes market exchange, the two are not identical. Rather, commodification is best understood as a set of relations both at the workplace and in personal consumption that systematically limits the potential for creativity and selfdevelopment that people inevitably strive to exercise, no matter how constrained the opportunities for doing so. To put it another way, the phenomenon of commodification ultimately is not simply imposed on people; it is a process that can be resisted with varying degrees of success. We need to consider how particular political strategies for empowering people could help bring about a social order in which the dilemmas posed by commodification would be less likely to arise in the first place. Focusing on such strategies will, I believe, provide the programmatic context that Radin's theory currently lacks, without requiring a necessitarian scheme of social change.

Radin's simultaneous erasure and exaltation of power reflects a failure to come fully to terms with what Roberto Unger has called the modernist insight: "[S]ociety is made and imagined, ... a human artifact rather than the expression of an underlying natural order." 30 The failure manifests itself as an oscillation between extremes. On the one hand, the appeal to consensus (or in other legal theories, to tradition, social values, and the like) represents an effort to find some aspect of difficult social and political questions that can be taken as given instead of up for grabs. It amounts to a denial, at least to the extent of the consensus, of the artifactual character of society. On the

29. See Radin, Market-Inalienability, supra note 9, at 1919 n.249 (noting the costs of decommodifying labor).

30. UNGER, supra note 12 , at 1. 
other hand, the single-minded focus on judicial decrees and legal rules, treating them as if they could be promulgated with virtually absolute effectiveness, represents an implicit assumption that society is utterly plastic.

This contradictory attitude toward the artifactual character of society marks most legal theorizing today, ${ }^{31}$ and severely undercuts the progressive potential of legal theory. Because it is executed with such insight, Radin's work provides a prime example of how that potential is undermined, and it is well worth examining in detail.

\section{Radin's Theory of Property and Personhood}

Radin's theory of property and personhood can be divided into two inquiries. The first seeks to determine what property is justifiably central to personhood. The second asks what action would be most appropriate to protect or vindicate justifiably personal interests. The answers to these inquiries form the basis of Radin's prescriptions for how the law should treat various forms of property.

Radin's first inquiry involves a descriptive and individualized determination: What is central to a particular individual's personhood? In other words, what property is crucial to the person's identity? For example, people may regard their home of many years as an extension of themselves. To them, a burglary would constitute a personal violation. ${ }^{32}$ However, the category of what is personal is not limited to objects; it also includes "personal

31. There are various, more specific ways of situating Radin's work. Eskridge and Peller describe an emerging genre of "New Public Law scholarship" that agrees with much of Critical Legal Studies views about "interpretative indeterminacy and the social construction of reality," but envisions a more centrist or reformist program of "dialogue, diversity, and pragmatic reasoning to achieve just social results." William N. Eskridge, Jr. \& Gary Peller, The New Public Law Movement: Moderation as a Postmodern Cultural Form, 89 Mich. L. REv. 707, 764, 787 (1991). Although their specific criticism of Radin's work lacks depth, see id. at 786, her work can be situated within the program they describe. One might also possibly relate Radin's project to what Mark Tushnet calls "center-left Burkeanism," in which liberals invoke traditional values. See MARK TUSHNEt, RED, WhITE, AND BLUE: A CRITICAL ANALYSIS OF Constitutional LAW $175-78$ (1988); see also UNGER, supra note 12, at 139-41 (describing a stance of "modest eclecticism" as one response to the predicament of social theory).

In the end, however, the most significant aspect of Radin's work for my purposes is what it shares with much of contemporary legal theory: an assumption that the aim of legal theorizing is what I have called "immediate persuasion." See Stephen J. Schnably, Beyond Griswold: Foucauldian and Republican Approaches to Privacy, 23 CoNN. L. REv. 861, 871 (1991) (arguing that much legal theorizing is undertaken with the implicit assumption that its task is an "immediate" form of persuasion, by which the Court directly responds with empathy and intellectual creativity to the reasoned appeals of individuals"); see also id. at 948-54. For a similar critique of legal scholarship, see Pierre Schlag, Normativity and the Politics of Form, 139 U. PA. L. REv. 801 (1991).

The assumption that legal academics' central task is to persuade courts or other policy makers what to do-an assumption that promotes inattention to the question of "how the prescription ... might realize itself in the social sphere," $i d$. at 879; see also Steven L. Winter, Without Privilege, 139 U. PA. L. REV. 1063, 1065 (1991)-inevitably if unintentionally tends to obscure the extent to which our society systematically disregards the very ideals (e.g., respect for personhood) to which normative legal practice appeals. In my view, to make that observation is not to reject normative judgment itself, but to question whether, taken in their current social context, conventional forms of academic theorizing are capable of mounting any serious critique of the existing social order.

32. Similarly, a wedding ring may take on sentimental value distinct from its market price. Radin, Personhood, supra note 16, at 959. 
attributes, relationships, and philosophical and moral commitments" that are "integral to the self." 33

This initial determination is not a matter of simple observation, because one might embody oneself in ways that we think are wrong or unhealthy. Thus, Radin searches for criteria to help distinguish things that people justifiably regard as central to their personhood from those that evidence fetishism. ${ }^{34}$ To make this distinction, she looks to a substantive conception of human flourishing. ${ }^{35}$ This notion of human flourishing rests on what Radin calls "objective moral consensus." 36 She does not set out her own theory of human flourishing, nor does she appeal to notions of natural law. ${ }^{37}$ The concept of human flourishing, in Radin's view, is informed by the normative judgments that society makes based upon its historical experience. ${ }^{38}$ These judgments are reliable in some sense, but never rise above challenge. ${ }^{39}$

Radin's conception of human flourishing appeals to intuitive judgments. She argues that we can distinguish justifiable embodiment from fetishism in roughly the same way that we can distinguish someone who is healthy from someone unhealthy. ${ }^{40}$ For example, according to Radin, the "compleat capitalist's" embodiment of self in control over enormous sums of money is not

33. Radin, Market-Inalienability, supra note 9, at 1905-06.

34. "Personal property marks out a category of things that become justifiably bound up with the person and partly constitutive of personhood. Thus, a normative view of personhood, and hence a normative view of human flourishing, is needed in order to identify which objects are appropriately personal." Radin, The Liberal Conception of Property, supra note 3, at 1687.

35. Radin uses "personal property" to identify things which promote human flourishing:

I have attached the label "personal" to property that is connected, and is understood morally as rightly connected to the proper development and flourishing of persons, understood primarily in its positive aspect, and I have attached the label "fungible" to property that is not connected to persons in this way but instead is understood as representing interchangeable units of exchange value.

Radin, Takings, supra note 6, at 257; see also Radin, The Liberal Conception of Property, supra note 3, at 1687 (arguing that, in the takings context, the Supreme Court should ask, "What conception of human flourishing - of personhood in the context of community-are we fostering by sustaining or disallowing" a particular statute?).

36. Radin, Personhood, supra note 16, at 969 .

37. Id.; see also id. at 961-62 (opting to seek "necessary objective criteria" by appeal to "the concept of person itself," rather than by "appeal to extrinsic moral reality, [or] to scientific truths of psychology").

38. See id. at $969 \mathrm{n} .44$ ("[O]ur present state of philosophical enlightenment on the subject of moral objectivity seems to be consonant with the argument that 'deep' moral consensus-not mere social consensus, or subjective preference counting - should be treated as objective for political purposes."); cf. Margaret Jane Radin, Cruel Punishment and Respect for Persons: Super Due Process for Death, 53 S. CAL. L. REv. 1143, 1176 \& n.109 (1980) (arguing that judges should rely on "coherent moral consensus of our society" to make moral judgments about appropriate punishment); Margaret Jane Radin, The Jurisprudence of Death: Evolving Standards for the Cruel and Unusual Punishments Clause, 126 U. PA. L. REV. 989, 1041-42 (1978) (arguing that courts should use "central moral concepts of our system on which there is a consensus" to determine what is cruel and unusual punishment).

39. Because society changes over time, Radin presents value judgments as mutable. For example, she carefully notes that the judgment that the home should be treated as personal is one society makes "in this time and place." Radin, Takings, supra note 6, at 259.

40. "We can tell the difference between personal property and fetishism the same way we can tell the difference between a healthy person and a sick person, or between a sane person and an insane person." Radin, Personhood, supra note 16, at 969; see also Radin, Market-Inalienability, supra note 9 , at $1908-09$. 
"well-developed."41 Similarly, it may be unhealthy to view one's body (or parts of it) as a commodity to be traded on the market. ${ }^{42}$ In contrast, people's involvement with their homes is healthy, ${ }^{43}$ as may be their embodiment in their cars. ${ }^{44}$

The ideal of human flourishing dictates that some embodiment is necessary to personhood, at least in our society today. According to Radin, respect for personhood requires us to reject "universal commodification," an archetype of social interaction in which all things, including personal attributes and body parts, may be sold.45 Universal commodification is wrong precisely because it leaves the person without any defining characteristics. ${ }^{46}$ Consequently, in the case of personal goods or attributes, Radin rejects the presumption that market intervention is justifiable, if at all, only to correct market malfunctioning. ${ }^{47}$

Just as she rejects universal commodification, Radin also finds its opposite-universal noncommodification-unsatisfying. Under universal noncommodification, no property in which the self is embodied may be bought or sold. ${ }^{48}$ In part, Radin's rejection of such a regime reflects her concerns about the transition difficulties that would arise during any effort to institute universal noncommodification; for example, she is sensitive to the charge that forbidding prostitution could simply provide a cover for further oppression of women whom society has already rendered powerless. ${ }^{49}$ She

41. "The empire of the 'compleat capitalist,'... might contribute to her continuity and to her own sense of fulfillment, but it would not contribute to her being a well-developed person, for the 'compleat capitalist' is not well-developed; she has embraced an inferior concept of human flourishing." Radin, Rent Control, supra note 20, at 365; see also Radin, Market-Inalienability, supra note 9, at 1908 ("An example of an unjustifiable kind of relationship is the involvement of the robber baron with an empire of 'property for power.' ") (citation omitted); Radin, Personhood, supra note 16, at 970 \& n. 48 ("Most people might consider ... . [the caricature capitalist] lacking in some essential attribute of personhood, such as the capacity to respect other people or the environment.").

42. See Radin, Market Domain, supra note 9, at 181-82, 187-88; Radin, Market-Inalienability, supra note 9, at 1913-14.

43. See Radin, Takings, supra note 6, at 257 ("Home-ownership carries greater moral weight in the legal system than does ownership of vacant land held for investment."); Radin, The Liberal Conception of Property, supra note 3, at 1689 ("The connection between people and residences is recognizable by us as normatively appropriate."); Radin, Market-Inalienability, supra note 9, at 1908 ("An example of a justifiable kind of relationship is people's involvement with their homes. This relationship permits self-constitution within a stable environment."); Radin, Personhood, supra note 16, at 987 ("There is both a positive sense that people are bound up with their homes and a normative sense that this is not fetishistic.").

44. See Radin, Personhood, supra note 16, at 1001 ("[T]he reverence for cars in the popular culture might suggest they are toward the personal end of the continuum.").

45. See Radin, Market-Inalienability, supra note 9, at 1859-63; Radin, Market Domain, supra note 9 , at $167-68$.

46. See Radin, Market-Inalienability, supra note 9, at 1881 ("Systematically conceiving of personal attributes as fungible objects is threatening to personhood, because it detaches from the person that which is integral to the person."); id. at 1905 ("Universal commodification undermines personal identity by conceiving of personal attributes, relationships, and philosophical and moral commitments as monetizable and alienable from the self.").

47. See id. at 1863-70.

48. See id. at 1871-77.

49. Id. at 1921-25; cf. Radin, Market Domain, supra note 9, at 169 (asserting that in some circumstances, measures to protect personhood may be "cruelly smug" because they harm the most vulnerable). 
also appears to believe, however, that even in an ideal society some goods could be treated as commodities without harming personhood. Nuts and bolts, for example, may exist entirely in commodified form without causing injury. ${ }^{50}$ Thus, Radin's ideal of human flourishing lies somewhere between the poles of universal commodification and noncommodification.

Radin also indicates that the ideal sometimes may be communitarian, rather than individualistic. ${ }^{51}$ We might, for example, be concerned about the personhood of a long-established community of low-income tenants whom rapid rent increases threatened to disperse. ${ }^{52}$ Moreover, just as an individual's fetishism can indicate bad or unhealthy personhood, so too can there be instances of bad community personhood. ${ }^{53}$

Beyond these general outlines, Radin offers no comprehensive theory of the ideal of human flourishing. Rather, she offers particular judgments about particular issues. Her omission of a comprehensive theory can be attributed to two considerations. First, because she bases her ideal of human flourishing on what she perceives to be society's deepest consensual values, the ideal extends only so far as there is any such consensus. Second, because she believes that our society is characterized by consensus in some respects, and by conflict in others, ${ }^{54}$ Radin's view can yield only particular consensual social judgments, not a comprehensive vision of human flourishing.

The second inquiry in Radin's approach requires us to determine how to treat the personal interests that we have identified in the first stage of the analysis. This determination has two components. The first consists of a decision as to which techniques to use to vindicate or protect the identified personal interests. The second component is an evaluation, in light of our nonideal circumstances, whether application of those techniques would be appropriate.

With regard to the first component, one method is to favor personal over

50. See Radin, Market-Inalienability, supra note 9, at 1912 ("[N]uts and bolts are pretty much the 'same' whether commodified or not, whereas love, friendship, and sexuality are very 'different'; ... trying to keep society free of commodified love, friendship, and sexuality morally matters more than trying to keep it free of commodified nuts and bolts.").

51. See Radin, Rent Control, supra note 20, at 368 ("The personhood argument can be seen ... to have communitarian roots if the necessary objective judgment about the category of personal property has a communitarian basis."); see also Radin, Personhood, supra note 16, at 1006 (referring to the possibility that courts implicitly recognize group property rights grounded in personhood concerns).

52. Radin does not assert whether a community has an existence distinct from the mere agglomeration of its individuals or whether it is simply a much valued instrument for individual satisfaction. See Radin, Rent Control, supra note 20, at 369. In any event, communities may find that their continued existence depends on continued attachment to a particular set of property.

53. In a mostly white, suburban, middle-class community, "people's involvement with their homes" may mean using zoning and other devices to exclude the poor and minorities. See notes 107110 infra and accompanying text. Radin addresses this concern with the assertion that excluding outsiders "is not per se pro- or anti-personhood or pro- or anti-community; the evaluation depends on the circumstances." Radin, Rent Control, supra note 20, at 380. Apparently this evaluation would rest on the same distinctions between personal and fetishistic interests-a conception of human flourishing. See id. ("The size of the community, its cohesiveness, and its need for exclusionary practices in order to survive as a community" would have to be considered.).

54. See, e.g., Radin, Takings, supra note 6, at 260-63. 
fungible property interests. ${ }^{55}$ For example, the state may, in effect, give tenants permanent tenure on good behavior by restricting the right of landlords to evict the tenants. Or the state may require a shopping center owner to permit protesters to demonstrate on the premises. In each case, the individuals with the personal interest (the tenants and the protesters) prevail over the individuals with the fungible property interest (landlords and mall owners). Favoring a personal interest could also mean giving it greater protection from state interference. For example, Radin suggests that the state might be required to give better reasons for taking someone's home by eminent domain than taking land held solely for investment. ${ }^{56}$ Or, even if we were to regard bodily organs as property, we would likely decide that the personal interest in them is so compelling that they could never be condemned. ${ }^{57}$

A second technique for protecting a personal interest is to decommodify it or make it market-inalienable, meaning that it can be given away but not sold. ${ }^{58}$ Our ideal of human flourishing indicates that some attributes or property should not exist in commodified form at-all, an assertion Radin calls the "prohibition argument." 59 A clear example is the prohibition of buying and selling human beings as slaves. Under this approach, we might also forbid people from selling their kidneys or their sexual services, on the ground that treating human bodies as commodities can never be consistent with human flourishing.

The decision how to treat identified personal interests involves an evaluation of whether decommodification is appropriate. This evaluation is more complicated than it first appears. Although the ideal of human flourishing provides primary guidance in deciding whether and to what extent to permit market-alienability, Radin argues that we may diverge from what the ideal's guidance would indicate. For one thing, there may be instances in which we should prohibit commodification that would otherwise be consistent with human flourishing. The principal justification for such a prohibition is the

55. Cf. Radin, Personhood, supra note 16, at $978-79$ ("[S]ome property is accorded more stringent legal protection than other property, or is otherwise deemed more important than other property by social consensus.").

56. See id. at 1005-06. Radin is careful to note that the law has not recognized a personhood limitation on the power of eminent domain, although she does not find that necessarily inconsistent with her theory:

[P]erhaps we are unwilling to presume that all single-family homes are personal because many houses are held only for investment, and a subjective inquiry into each case slows down government too much. On the other hand, perhaps the personhood perspective is so deeply embedded that, without focusing on the problem, we expect that the condemning authority will take fungible property where possible.

Id. at 1006.

57. Cf. Radin, Takings, supra note 6, at 260 ("If we conceive of the body as property, can kidneys be condemned for public use?").

58. Radin, Market-Inalienability, supra note 9, at 1850, 1875-76.

59. Id. at 1912. Radin does not argue that all personal property should be fully decommodified. See id. at 1911 n.227 (noting that personal things like "family heirlooms or a homestead" may be sold, although we might want to scrutinize the terms of the sale more closely given their personal nature). 
"domino effect."60 For example, although some goods or attributes could theoretically exist in both fungible and personal versions, ${ }^{61}$ we might fear that complete commodification eventually would follow partial commodification.62 We may wish to prohibit the commodified version of a good or attribute in order to prevent such an outcome. ${ }^{63}$

There also may be instances, Radin argues, where the ideal of human flourishing points toward decommodification, but we may hesitate to follow through in light of other circumstances. These circumstances include the fact that we live in a nonideal world and that any transition to an ideal world entails special considerations. ${ }^{64}$ The analysis thus requires nonideal evaluation. ${ }^{65}$ The need for nonideal evaluation manifests itself in two overlapping ways: the "double bind" 66 and the transition problem. ${ }^{67}$

The dilemma of the double bind is posed by the possibility that, in prohibiting market-alienability, we may harm the very people we mean to protect. Thus, if we prohibit a poor person from selling one of her kidneys, we deprive her of money that she may desperately need. 68

Difficulties may also arise during the transition from commodification to decommodification. For example, we might think that awarding money damages in tort cases for pain and suffering or for loss of companionship commodifies people's very existence by placing a dollar value on their lives and feelings. A simple ban on the award of such damages, however, without implementing other measures of compensation or care, would be unfair to those who have suffered the injury. In other words, Radin asserts, allowing damages for pain and suffering and for loss of companionship during the transition to decommodification is a more just alternative. ${ }^{69}$

Recognition of the double bind and transition difficulties leads Radin to favor "incomplete decommodification."70 She suggests that we might permit some limited right to sell a personal interest. For example, we might refrain from criminalizing the sale of a personal interest, but also refuse to enforce a contract of sale.

An example may help give substance to Radin's subtle and perceptive

60. Id. at 1912-14.

61. But see id. at 1923 n.260 (describing the argument that "the commodity form of a thing might drive out the noncommodified version of the "same" thing" and noting that the "domestic services market ... does coexist with a parallel class of unpaid providers").

62. See id. at 1912-14.

63. For an example of a possible "domino effect" involving prostitution, see notes 71-78 infra and accompanying text.

64. See Radin, Takings, supra note 6, at 266.

65. See id.

66. See Radin, Market-Inalienability, supra note 9, at 1915-17.

67. See id. at 1875-77; Radin, Takings, supra note 6, at 266.

68. Cf. Radin, Market-Inalienability, supra note 9, at 1915-16 (noting argument that "[i]f the law denies women the opportunity to be comfortable sex workers and baby producers instead of subsistence domestics, assemblers, clerks, and waitresses - or pariahs (welfare recipients) and criminals (prostitutes) - it keeps them out of the economic mainstream and hence the mainstream of American life.").

69. Id. at 1876-77.

70. See id. at 1917-21. 
arguments about nonideal evaluation. She begins her discussion of prostitution with a prohibition argument: We might well want to forbid prostitution entirely, based on a normative assertion that sexuality should not be a commodity at all. ${ }^{71}$ Radin then considers the possibility of a domino effect. If sex were fully advertised as a commodity, it is possible that "[a] change would occur in everyone's discourse about sex, and in particular about women's sexuality."72 It might become impossible for men and women to conduct sexual relationships on the basis of an "ideal of sexual interaction as equal nonmonetized sharing."73

After canvassing the reasons to outlaw prostitution, Radin engages in nonideal evaluation and finds two problems with banning prostitution. First, the problem of the double bind is exacerbated. When prostitution is illegal, we may harm some women:

Poor women who believe that they must sell their sexual services to survive are subject to moral opprobrium, disease, arrest, and violence. The ideal of sexual sharing is related to identity and contextuality, but the identity of those who sell is undermined by criminalization and powerlessness, and their ability to develop and maintain relationships is hurt by these circumstances. ${ }^{74}$

Second, banning prostitution in an effort to decommodify sexuality may amount to hypocrisy. Radin notes that sexuality may already be commodified to a large extent (by which she means primarily that prostitution is widespread). ${ }^{75}$ She also discusses the possibility that "male-female sexual relationships that actually instantiate the ideal of equal sharing are under current social circumstances rare or even impossible." 76 If we prohibit prostitution in the name of the ideal, we may simply deceive ourselves and oppress women, especially those whose "class or race forecloses more socially accepted forms of sexual bargaining."77

In light of our nonideal circumstances, Radin proposes partial decommodification rather than full market-inalienability: She would allow prostitution, but not brokering, advertising, or contract enforcement. She reaches this conclusion by balancing the dangers of commodified sexuality against the cautions introduced by nonideal evaluation. ${ }^{78}$

71. Id. at 1921; see also id. at 1908 ("Commodified sex leaves the parties as separate individuals and perhaps reinforces their separateness; they only engage in it if each individual considers it worthwhile. Noncommodified sex ideally diminishes separateness; it is conceived of as a union because it is ideally a sharing of selves.").

72. Id. at 1922.

73. Id. at 1921.

74. Id. at 1922; see also id. at 1915-16.

75. Id. at 1921 \& n.256. Interestingly, Radin makes no reference here to the pervasive way that sexuality is used in advertising and thereby made a part of the system of commodities. For elaboration on this point, see notes 207-208 infra and accompanying text.

76. Radin, Market-Inalienability, supra note 9, at 1922.

77. Id. at 1923.

78. Id. at 1924-25 \& n.261. Radin's analysis of baby-selling proceeds along similar lines. See $i d$. at 1925-28. Her principal concern is that it may be too damaging to everyone's personhood to permit any use of market rhetoric or mechanisms in deciding who will raise a child. Id. at 1927. Consequently, she proposes that babies be made market-inalienable, rather than simply being par- 
As even this brief summary makes clear, Radin's analysis constitutes a rich and highly contextual explication of the relationship between property and personhood. Her approach is all the more interesting because it seems pragmatic. Radin does not just point to the possibility of a double bind or transition difficulty, and she does not simply tell us to restructure society so that our problem will be easier to solve. Because she recognizes that thoroughgoing restructuring will not happen overnight and that it is not clear what a reconstructed society should be like, she seeks to offer transitional solutions for the here and now. The very attractiveness of her approach, however, makes an investigation into its shortcomings all the more important.

\section{Personhood as an Arena of Power and Resistance}

Radin's approach has two key aspects. The first is an attempt to bracket at least some normative issues and to apply a given consensus; the second is a tendency to treat power as absolute. These characteristics deprive Radin's theory of adequate tools either to account for, or to advocate, systemic social change. In the following sections, I will elaborate on these aspects and suggest two heuristic guides to help address the issues they raise.

The two heuristics are intended to help avoid the potentially conservative implications of Radin's approach. First, rather than attempt to search out and identify ideals as manifested at some general level of deep social consensus, we ought to look for tensions in those ideals, even where-in fact, particularly where-consensus seems strongest. In doing this we ought to be sensitive to the power relations that often contribute to the shaping of consensus in its concrete form. One way to heighten our sensitivity to the inevitably controversial character of widely shared norms is to identify the ways in which policies carried out in the name of those norms actually help create or compound social problems.

Second, rather than attempt to ferret out ways in which the law purportedly recognizes ideals of human flourishing, we should focus on people's struggles to constitute personhood in conformity with their differing ideals of what it should be. The ultimate aim of our analysis should not be to facilitate the law's implementation of ideals we all supposedly share, but to heighten our awareness of the conflicts that arise over the concrete meanings

tially decommodified. Id. at 1927-28. At base, her insistence on full decommodification even in a nonideal world seems to rest on her belief that "our aversion to commodification of babies," $i d$. at 1928 , is stronger than our aversion to commodification of sexual services.

Radin's analysis of surrogacy is more tentative. She notes the interest in preventing women from being fully commodified-treated as fungible wombs, hired for a fee to carry men's children. See id. at 1928-30. She is also concerned about the possible domino effect, noting ways in which widespread use of surrogacy contracts might undermine noncommodified adoption. Id. at 1930-32. Further, permitting surrogacy may simply reinforce traditional stereotypes about women and reproduction. Id. at 1930 \& n.279. Once again, though, she is sensitive to the double bind in the form of "even further oppression of poor or ignorant women." Id. at 1930. She ends with a weak preference for "a form of market-inalienability similar to our regime for ordinary adoption" over partial decommodification. Id. at 1936. 
of those ideals. These contests over personhood become more evident once we recognize the socially mediated nature of any given connection between property and personhood. In contrast, Radin consistently portrays personal interests in a direct, unmediated way, and envisions the resolution of conflicts involving personhood only in terms of the application of state power to protect passive objects. This approach, I will argue, obscures the reality that even the least powerful in our society still struggle for their interests in disputes over property and personhood.

In short, the first heuristic points us to the contestable nature of seemingly consensual social norms; the second, to the fact that such norms are indeed contested. In the following sections, I will discuss the weaknesses of Radin's theory and demonstrate how these two guides make possible a more insightful analysis of property and personhood.

\section{A. The Appeal to Consensus}

Central to Radin's approach is the assumption, shared by many legal theorists, that we can consider at least some legal issues separately from the deeply controversial normative disputes that determine what people are and should be like. This assumption appears to reflect a judgment that we can sometimes bracket, or take as given, the normative question of how we as a society come to view certain property as justifiably personal. ${ }^{79}$ When judges or legislators decide to give heightened protection to the home, for example, they simply apply a normative judgment drawn from a particular vision of human flourishing that is assumed to be held by our society.

One could understand Radin's bracketing of certain areas as nothing more than a prudent effort to keep the discussion within reasonable limits. It certainly is not a denial of the fact that conflict and disagreement have a very real part in our society. ${ }^{80}$ Rather, she seems to say that, although we may not agree on everything, we do agree that people should be permitted and encouraged to foster their own personhood, and that agreement entails at least some definite consequences. Interesting points can be made about property and personhood without fully elaborating and defending a general conception of human flourishing.

A more ambitious aim, however, appears to lie behind Radin's strategy of bracketing normative questions: preserving the very possibility of the rule of law. Rejecting the notion that language alone can ever provide determi-

79. Interestingly, there is a parallel between the technique Radin uses to develop her theory of property and personhood and that used by law and economics scholars. Both separate legal issues from very controversial moral and political disputes concerning human characteristics and aspirations. Radin takes the ideal of human flourishing as given for purposes of applying a rule at any particular time in a given society. Mainstream economists take people's tastes or preferences as given for purposes of economic analysis. See, e.g., JACK HIRSHLeifER, PRICE TheORY AND APPLICATIONS 127 (1976).

80. Radin's argument plainly is not that some deep consensus governs every aspect of our society, but that there are at least some areas of deep consensus. Nor is her argument that the areas of consensus that do exist will remain as such forever, or that they represent universal values; particular consensual judgments are valid "in this time and place." Radin, Takings, supra note 6, at 259. 
nate rules, ${ }^{81}$ Radin looks to shared social understandings as the basis for a rule-like character of the law. ${ }^{82}$ Resting her analysis on a reading of Wittgenstein that defines rules as essentially social and communitarian practices, ${ }^{83}$ Radin concludes that if there is to be any possibility of the rule of law, we must be "one [community] in at least some sense(s)." attempts to identify at least some deeply embedded consensual values that justify the application of legal rules. For the attempt to succeed, Radin must make two assumptions about any given consensual social judgment: first, that such a consensus, fairly-formed, exists; and, second, that application of the consensual norms of personhood is somehow distinct from their constitution.

Both assumptions are wrong. I will argue that there is never any true consensus to follow. If we examine any particular area of "consensus" closely, we will find deep disputes as well. Indeed, it is precisely with respect to those values that seem most obviously uncontroversial that we should be most skeptical. Moreover, even if we could identify some specific areas of consensus, it would be impossible merely to follow the guidelines of that consensus. Each time we purport merely to follow a given consensual norm, we help constitute personhood in a way that reinforces that norm. Consequently, because the process of drawing on consensus simultaneously fosters and creates consensus, it is circular to try to draw on a given "consensus" to guide the resolution of legal issues.

\section{The nonexistence of consensus.}

The assumption of fairly formed consensus raises several questions. For example, to what degree is there really consensus over the issues pertaining to property and personhood? How do we know that the consensus does not simply reflect unjustifiable inequalities in power?

Once one acknowledges these issues, it becomes essential to conduct a detailed and critical analysis of the fairness of the processes by which contests over values are resolved, and indeed of the extent to which they produce any consensus at all. Although Radin takes note of the possibility that there are no consensual values-that there is no one "we" to be the subject of consensual values, ${ }^{85}$ she does not systematically explore that possibility or develop its implications. ${ }^{86}$

81. See Radin, Rule of Law, supra note 3, at 814 ("A pragmatic reinterpretation of the Rule of Law would at least deny that law consists of formally realizable rules in the traditional sense.").

82. Id. at 799-800 ("Only the fact of our seemingly 'natural' agreement on what are instances of obeying rules permits us to say there are rules. The rules do not cause the agreement; rather, the agreement causes us to say there are rules.").

83. See id. at 797-801.

84. Id. at $816 \mathrm{n} .121$.

85. See Radin, Pragmatist, supra note 7, at 1710-11 ('Dominant groups have tended to understand themselves without question as the only 'we,' whereas oppressed groups, simply by virtue of recognizing themselves as an oppressed group, have understood that there can be plural 'we's.' "); Radin \& Michelman, Critical Legal Practice, supra note 7, at 1047-48 (calling upon legal scholars to be careful when searching for a deep moral consensus).

86. On the contrary, the recognition of some kind of deep social consensus remains basic to her 
Nor does Radin engage in any extended analysis of the possibility that, even if there are values deeply embedded in our society, those values might be morally wrong. She does discuss what she calls "bad coherence," recognizing that coherence can be based on domination and oppression. ${ }^{87}$ She briefly considers the possibility that in our society property itself is deeply anti-personhood, ${ }^{88}$ and takes note of what she calls the position of "revolutionary noncommodification." The latter "holds that the capitalist structure permeates not only our world of social interaction and allocation of resources but also our discourse, vocabulary, and conception of human flourishing." 89 These remarks might suggest a basis for strong skepticism toward any effort to guide our views on personhood by some deep moral consensus. Radin's decision, however, not to explore in depth the troubling indications of a lack of true consensus may well reflect a conviction that there are at least some significant areas of deep consensus or agreement, and that existing inequalities of wealth and power do not vitiate the moral relevance of that consensus. I would question, however, whether our efforts are well spent attempting to draw conclusions from what are thought to be areas of agreement. Once we look beneath the surface of virtually any consensual or objective ideal, tensions immediately become apparent.90

Consider Radin's assertion that "people's involvement with their homes [is justifiable because it] ... permits self-constitution within a stable environment."91 At this level of abstraction-a level typical of many assertions in contemporary legal theory concerning social values-her characterization of people's relationship to their homes may well seem intuitively obvious. But the statement remains valid only if we disregard the actual social context in which people relate to one another and to their property. In fact, people's involvement with their homes is nowhere near as simple and uncontroversial as Radin's presentation suggests.

It will be helpful to begin by unpacking the home as an ideal. Consider the modern suburban home, which has its roots in the nineteenth century, ${ }^{92}$

approach to law. See Radin, Personhood, supra note 16, at 969 n.44 (suggesting that "deep" moral consensus "should be treated as objective for political purposes"). In later works, Radin's treatment of objectivity is more tentative, but she still takes it as given that we must be "one in at least some sense(s)" for the rule of law to be possible:

It seems to me that "we" are one community on the issue of whether $2+2=4$, but perhaps we are many diverse communities on other issues more readily regarded as ethical, religious, or political. The pragmatic normative significance of our having a constitution is to deny at least the furthest reaches of such pessimistic irreconcilable pluralism.

Radin, Rule of Law, supra note 3, at $816 \mathrm{n} .121$; see note 84 supra and accompanying text.

87. Radin, Pragmatist, supra note 7, at 1710-11; see note 85 supra and accompanying text.

88. See Radin, Personhood, supra note 16, at 970.

89. Radin, Market-Inalienability, supra note 9, at 1875.

90. The existence of tensions in the ideals that we "share" does not mean that there never can be any degree of common ground in our society as to what constitutes human flourishing. Perhaps even the most ardent adherent of market solutions to social problems would find a burgeoning market in human kidneys at least somewhat degrading to personhood. But no meaningful conclusions about particular issues will follow from consensus at such a general level; focusing on some highly general level of consensus thus is unlikely to be productive.

91. Radin, Market-Inalienability, supra note 9, at 1908.

92. See generally John R. Stilgoe, Borderland: Origins of the American Suburb, 
but really came into its own in the post-World War II era. ${ }^{93}$ Plainly, this is what Radin has in mind when she speaks of the home: "The 'home'-usually conceived of as an owner-occupied single-family residence-seems to be a paradigm case of personal property in our social context."94 Even for the many people who cannot in fact afford a private home, it remains an aspirational ideal.

More particularly, the home represents a whole set of assumptions and lived experiences. It is impossible to think about the meaning of the home and its connection to personhood without thinking about its larger context. For example, the ideal of the home goes hand in hand with the assumption that fulfillment is primarily to be found in private life, rather than in communal activities. ${ }^{95}$ Like its essential counterpart, the shopping mall, the suburban home represents in many ways the rejection of public spaces. ${ }^{96}$

Moreover, an essential part of our attachment to the home, suburban or otherwise, is grounded in its status as the privileged locale for intimate relationships. ${ }^{97}$ The home and family are practically inseparable not only in their conception, but also in their history: The rise of the home as an ideal and social practice was closely linked to the creation of women's role as homemakers. ${ }^{98}$ Furthermore, one precondition to the development of the home as a private refuge from public life was the separation of production from family life. ${ }^{99}$ In that sense, the family is as much a creation of the labor market as it is a refuge from it.

The ideal of the home also embodies ideas that extend beyond the confines of domestic roles. One of those ideas is the notion that local communi-

1820-1939 (1988). Cf. Stephanie CoONTz, The Social Origins of Private Life: A History OF AMERICAN FAMILIES 1600-1900, at 251-329 (1988) (noting the diversity of family types by class and race even as the modern ideal of the family was being formed).

93. See, eg., Norval D. Glenn, Suburbanization in the United States Since World War II, in The URBanization of THE Suburbs 51, 55-56 (Louis H. Masotti \& Jeffrey K. Hadden eds., 1973) (discussing sharp growth of suburban population in the period from 1950-1970).

94. See Radin, Rent Control, supra note 20, at 364 .

95. The psychology of the suburbs reflects and reinforces this ideal: "The relative isolation of people in [the suburban town of] Hampton from strangers is not only a fact of social morphology but also a moral expectation. ... [I]ndividuals who use the streets or other public places more than is customary, especially for socializing, are seen as deviants." M.P. BAUMGARTNER, THE MORAL ORDER OF A SUBURB 103 (1988).

96. Id. at 101-02. This rejection reflects a larger turn away from any notion of public culture. See Richard Sennett, The Fall of Public Man 259-68 (1976).

97. See Gwendolyn Wright, Prescribing the Model Home, 58 SOC. RES. 213, 224 (1991) ("Home conveys other privileges as well: privacy, freedom from intrusions, autonomy for the family and for consenting adults.").

98. See Kenneth T. Jackson, Crabgrass Frontier: The Suburbanization of the UNITED STATES 300 (1985) ("The dream house was designed around the needs of a bread-winning male and a full-time housewife who would provide her prince with a haven from the cold outside world ...."); $c f$. MARTHA MINOW, MAKING ALl THE DIFFERENCE: INCLUSION, EXCLUSION, AND AMERICAN LAW 269-71 (1990) (discussing the role of traditional family law in reinforcing genderbased roles). For an excellent historical account of the suburban home and its relation to women's roles, see MARGARET MARSH, SubuRban LIVEs (1990); see also COONTZ, supra note 92, at 338-39 (emphasizing tensions within the ideal of domesticity and women's rules).

99. See Stephen J. Schnably, Normative Judgment, Social Change, and Legal Reasoning in the Context of Abortion and Privacy, 13 N.Y.U. REv. L. \& Soc. ChaNGE 715, 854-55 (1984-1985). 
ties should be comprised of people of the same race and economic status. This idea has become so rooted in people's everyday experience of suburban life that it seems utterly natural. What diversity is to be found lies only in an ersatz individuality exemplified by the pasting of different architectural styles onto cookie-cutter homes. ${ }^{100}$ It is a telling mark of the artificiality of such styles that Palos Verdes, a Los Angeles suburb developed in the 1920s, mandated Mexican-style architecture even as it excluded Mexican-Americans by means of restrictive covenants. ${ }^{101}$ Finally, in its most suburban form, the ideal of the home represents the idea that problems of urban living can be resolved by abandoning them ${ }^{102}$ and that the automobile provides a private solution to public transportation needs. ${ }^{103}$

Once one thinks more concretely about the home, doubts about its healthiness are hard to suppress. In fact, people have called into question each conception of the home mentioned above. By undermining the cult of domesticity, the entry of women into the labor force has had a profound impact on the suburban ideal of the home. ${ }^{104}$ Indeed, the idea of the family as a haven, a private world separate from power-perhaps the most defining aspect of the home-has come under attack by feminists, who have shown that it has contributed greatly to the subordination of women. ${ }^{105}$ These attacks have been both theoretical and practical, constructive as well as critical. Setting up shelters for battered women represents one example. The efforts of single mothers or of lesbians and gay men to create families outside the model of the nuclear family provide others. ${ }^{106}$ These efforts should

100. See Stuart Ewen, All Consuming Images: The Politics of StYle In ContempoRARX CULTURE 229-30 (1988); MARSH, supra note 98, at 168 (noting that in the Los Angeles suburbs, developers "attempted to create architectural harmony and to exclude any heterogeneity of race or class"); Wright, supra note 97, at 213, 221-23.

101. See MARSh, supra note 98, at 172-73; GWENDOLYN WRIGHT, BuILDING THE DREAM: A SOCIAL HISTORY OF HOUSING IN AMERICA 212 (1981) ("The quaint stylistic diversity of American suburban architecture belied hostilities against ethnic minorities."). The residents of Palos Verdes eventually resolved the contradiction by calling their architecture "Californian." MARSH, supra, at 175.

102. See JACKsoN, supra note 98 , at $272-82$.

103. To be sure, the dream of home ownership can encompass a condominium in the city as well. But there is no doubt that the ideal of the suburban home has had much to do with the general neglect of public transportation, even in the cities. On the relation between the automobile and the growth of a whole way of living and working around it, see id. at 246-71; WRIGHT, supra note 101, at 205-08.

104. See MARSH, supra note 98 , at $187-88$.

105. See, e.g., Elizabeth M. Schneider, The Violence of Privacy, 23 CoNN. L. REv. 973 (1991); see also Schnably, supra note 31, at 876-77 \& nn.59-62 ("The bedroom can be a closet as much as a sanctuary. It can also be . . . a place of coercion, an arena in which men dominate women.").

106. See Fajer, supra note 4, at 564-68 (challenging Supreme Court's claim in Bowers v. Hardwick, 478 U.S. 186 (1986), that gay life does not involve "family"); Barbara Omolade, The Unbroken Circle: A Historical Study of Black Single Mothers and Their Families, in AT THE BOUNDARIES OF LAW: FEMINISM AND LEGAL THEORY 171 (Martha Albertson Fineman \& Nancy Sweet Thomadsen eds., 1991) (examining the long history of black single-mother families); see also Martha Albertson Fineman, Intimacy Outside of the Natural Family: The Limits of Privacy, 23 CoNN. L. REv. 955 (1991) (concluding that the view of single mothers as deviant from "natural family" prevents adequate protection of single mothers' privacy); Washington Ordinance Tests Congress, N.Y. TIMES, Mar. 10, 1992, at A15 (noting the passage of an ordinance allowing registration of "domestic partners" in Washington, D.C.). 
make us wary of any simple blessing of the traditional home. The home is as much a place of domination and resistance, conflict and discord, as it is the center of a "healthy" life. To be sure, the identification of private life with the nuclear family ties the ideal of intimacy so closely to the reality of unequal power that any questioning of that power is often perceived as an attack on the very possibility of intimacy itself. My aim, however, is not to denigrate the need for intimacy, but to emphasize that the home today is far more a locus of conflict and struggle-both personal and social-than a bland reference to "people's involvement with their homes" could ever capture.

Nor have other aspects of the ideal of the home gone unquestioned. The famous Mount Laurel cases attacked exclusionary zoning, a practice that contributes to the division of housing into exclusive racial and socioeconomic enclaves. ${ }^{107}$ Urban planners have increasingly called into question other basic tenets of suburban development in the post-War era, such as the concentration on providing each home with its own yard to the exclusion of any common area, or the placement of houses outside walking distance from stores. ${ }^{108}$ There is increasing recognition that unmanageable traffic and pollution are the inevitable concomitants to sprawling suburbs, as well as a greater sense of the limits to the demands that we can put on the environment in the name of growth. ${ }^{109}$ Finally, the suburban shopping mall has

107. See Southern Burlington County NAACP v. Township of Mount Laurel, 67 N.J. 151, 336 A.2d 713 (holding that all municipalities in the state have a duty to provide a realistic opportunity for affordable low- and middle-income housing), cert. denied, 423 U.S. 808 (1975); see also Paul K. Stockman, Note, Anti-Snob Zoning in Massachusetts: Assessing One Attempt at Opening the Suburbs to Affordable Housing, 78 VA. L. REv. 535, 550-59 (1992) (describing the requirements of the Massachusetts Low and Moderate Income Housing Act and its interpretation by the Massachusetts Supreme Judicial Court in Board of Appeals v. Housing Appeals Comm., 363 Mass. 339, 294 N.E.2d 393 (1973)). There also have been efforts to create planned communities with a diversity of income classes. See, e.g., Heidi Daniel, Project Loses Its Originator, N.Y. TIMES, Oct. 27, 1991, § 10, at 8 . As the experience of New Jersey after the Mount Laurel cases demonstrates, the actual impact of these efforts is another question. See generally Martha Lamar, Alan Mallach \& John M. Payne, Mount Laurel at Work: Affordable Housing in New Jersey, 1983-1988, 41 RuTGERS L. REV. 1197 (1989).

108. See Lucie White, Representing "The Real Deal," 45 U. MiamI L. Rev. 271, 285-86 (1990-1991); see also Peter Calthorpe, Pedestrian Pockets: New Strategies for Suburban Growth, in The Pedestrian Pocket Book: A New Suburban Design Strategy 7, 11 (Doug Kelbaugh ed., 1989) ("[T] $]$ he present suburban environment is not walkable, much to the detriment of children, their chauffeur parents, the elderly, and the general health of the population."); Jane Holtz Kay, Rebellion Spreads for Walkable Cities, N.Y. TIMES, May 2, 1991, at C10 (noting that "a new generation of urban design advocates" is promoting "walker-friendly design to improve the lot of the hapless pedestrian"); Elizabeth Plater-Zyberk, Cities by Accident-or by Design? Sprawl threatens our resources, MIAMI HERALD, Mar. 22, 1992, at 1C ("Besides damaging the natural environment, suburban sprawl also threatens to decant the core of many of our cities and towns to nothingness in a matter of years."); Timothy J. Trainor, "Traditional Neighborhoods" Make Gains, N.Y. TIMES, Aug. $19,1990, \S 10$, at 3 ("The chief aim of the traditional-neighborhood proponents is to integrate both public and private uses into a more traditional urban grid system of streets, squares, parks and amenities. Its foremost concern is pedestrian accessibility to everyday needs and then the accommodation of the automobile as a modern necessity.").

109. See JACKSON, supra note 98, at 296-303; see also John Dorschner, Road to Ruin: When All the Highway Construction Is Finally Over, We Will Have Built Ourselves One Big Traffic Jam, Miami HeralD, July 10,1988, TROPIC, at 8 (noting the impossibility of building enough highways to handle traffic and arguing for efforts to bring jobs and housing in closer proximity). 
been criticized by urban planners, who want to remake it so as to resemble the traditional town square, and by protesters who fear that the private ownership of shopping malls may thwart their exercise of First Amendment rights. ${ }^{110}$

Debates over commodification of the body, which includes the sale of organs, babies, and sexual or reproductive services, also demonstrate the lack of consensus. Radin seems implicitly to rely upon some form of objective consensus concerning bodily integrity. For example, she appears to assume that prostitution would not exist in a world that completely embraced the ideals of our society. ${ }^{111}$ This assumption is dictated by the ideal of sexual relations that Radin calls "nonmonetized equal sharing." 12 In the case of organ sales and surrogacy, the relevant ideal underlying Radin's analysis seems to be that we should not treat our bodies as sources of fungible, marketable components. ${ }^{113}$

These characterizations of consensus are so general that they seem meaningless. Perhaps this explains why Radin rarely refers explicitly to consensual ideals in her consideration of commodification and the body. Although

110. On attempts to reconfigure suburban malls to make them the centerpiece of newly-developed "downtowns" with nearby housing, see, for example, Barbara Flanagan, A Suburban Mall is Now "Downtown," N.Y. Times, Mar. 14, 1991, at C1. The Supreme Court has held that the First Amendment does not protect peaceful protest on shopping center grounds, Hudgens v. NLRB, 424 U.S. 507, 512-21 (1976), but that the Fifth Amendment does not preclude a state from requiring shopping centers to give access to protesters. Pruneyard Shopping Ctr. v. Robins, 447 U.S. 74, 82-85 (1980); cf. Robins v. Pruneyard Shopping Ctr., 23 Cal. 3d 899, 592 P.2d 341, 153 Cal. Rptr. 854 (1979) (holding that the California Constitution protects speech and petitioning reasonably exercised, in privately-owned shopping centers); Batchelder v. Allied Stores Int'l, 388 Mass. 83, 445 N.E.2d 590 (1983) (holding that a candidate has a right to solicit signatures on a petition for ballot access under state constitution).

Efforts by protesters to distribute leaflets or picket in shopping malls demonstrate how little is gained by focusing on consensus. These challenges, in Radin's view, implicate a deeply embedded social preference for personal expression and self-development over the pursuit of profit. In Radin's terminology, the shopping center owner has only a fungible interest-making a profit-while protesters have a personhood interest-expressing their views. Radin argues that legal protection for the protesters should follow as the consequence of a deep social consensus that favors personhood over pure monetary interests. See Radin, Personhood, supra note 16, at 1008-09.

These cases, however, are better interpreted as demonstrating a lack of consensus concerning personal development. Shopping mall owners do not seek to stifle all personal expression, but rather to channel it into forms compatible with consumer culture. Thus, the real choice with respect to expressive activity at shopping malls is between an environment designed only to spur personal fulfillment through consumption and an environment that functions as a locus for collective, public debate over political issues as well. Radin's assumption that our society favors personal expression over fungible interests obscures that choice and inevitably blunts critical examination of the forces that systematically promote self-realization through consumption of goods.

111. Of course, Radin's conclusion that partial decommodification is the best way to deal temporarily with prostitution rests on nonideal considerations as well. See Radin, Market-Inalienability, supra note 9 , at 1921-25.

112. Id. at 1921-22; see also id. at $1917 \mathrm{n} .244$ ("unmonetized sharing"); id. at 1923 ("interpersonal sharing").

113. See id. at 1928-36; Radin, Market Domain, supra note 9, at 187-88; see also A.M. Capron \& M.J. Radin, Choosing Family Law over Contract Law as a Paradigm for Surrogate Motherhood, 16 LAW, MED. \& HEALTH CARE 34, 36 (1988) ("What is probably most remarkable about the debate over surrogate motherhood is that it has necessitated defending a claim that was previously taken as self-evident: namely, that society has an interest in people being regarded as intrinsically valuable, not as monetized units in a marketplace."). 
her discussions of prostitution and surrogacy evince far greater awareness of social conflict than does her analysis of other issues, she neither explores these conflicts at length nor abandons her assumption of underlying agreement. ${ }^{114}$

A more sustained focus on our ideals regarding the body and sexuality, examining the differing visions that seem to underlie opposition to commodification of the body, would reveal deep disagreements over the concept of human flourishing. For example, some might be concerned that sales of body parts would exacerbate inequalities of race, income, and gender. The poor-who tend disproportionately to be women and minorities-would not only be more likely to sell their organs, ${ }^{115}$ but also might face discrimination and economic exploitation in the agreements they made. ${ }^{116}$ Similarly, some might fear that widespread surrogacy would extend men's power over women's reproductive choices, thereby embedding women more deeply in existing structures of race, gender, and class discrimination. ${ }^{117}$ Finally, the prospect of legalizing prostitution might raise a similar concern: Prostitution objectifies women and encourages men to view them as instruments of pleasure. ${ }^{118}$

An alternative set of values, however, might produce uneasiness about commodification. For example, a different sort of concern might be that the sale of body parts is contrary to human nature, or arrogates to humankind a god-like role. Similarly, surrogacy might trouble some because it entails taking conscious human control over reproduction and turns women into active

114. For example, with regard to prostitution, Radin acknowledges that "nonmonetized equal sharing" may not currently be attainable in our society. Radin, Market-Inalienability, supra note 9, at 1922-23. But she never questions that it remains a widely and deeply held value.

115. See Chris Hedges, Egypt's Desperate Trade: Body Parts for Sale, N.Y. TIMEs, Sept. 23, 1991, at Al; Onyeanusi v. Pan Am, 952 F.2d 788, 792 n.6 (3d Cir. 1992).

116. Minorities and lower income people would likely fare no better as sellers in the market than they would as consumers. See generally ALAN R. ANDREASEN, THE DISADVANTAGED CoNSUMER (1975); Ian Ayres, Fair Driving: Gender and Race Discrimination in Retail Car Negotiations, 104 Harv. L. Rev. 817 (1991). Cf. Jane Maslow Cohen, Posnerism, Pluralism, Pessimism, 67 B.U. L. REV. 105, 172 (1987) (suggesting that many lower income women "will sell themselves short in a Posnerian baby market because they do not understand their true costs, they cannot present value their future losses, [and] their bargaining ability will be undercut by their still-less-sophisticated sisters").

117. At the same time, feminists do not subscribe to a monolithic position on surrogacy and related issues. Compare Carmel Shalev, Birth Power: The Case for Surrogacy 166 (1989) (justifying surrogacy contracts as feminist because they embody women's "personal human agency" in reproductive decisions, "regardless of gender") with Barbara Katz Rothman, Surrogacy: $A$ Question of Values, in BEYOND BABY M: ETHICAL IsSUES IN NEW Reproductive TechNiques 235, 237, 240, 239 (Dianne M. Bartels, Reinhard Priester, Dorothy E. Vawter \& Arthur L. Caplan eds., 1990) (raising "radical feminist" objection that surrogacy "reduces the woman to a container" and reinforces "patriarchal values"). Radin's brand of feminism similarly may be distinguishable from a more liberal approach. See Margaret Jane Radin, Reflections on Objectification, 65 S. CAL. L. Rev. 341, 350-51 (1991) (distinguishing feminism that, like Shalev's, takes a liberal approach from one that is concerned with preserving women's personhood).

118. Radin insightfully discusses these concerns in the context of surrogacy and prostitution. See Radin, Market-Inalienability, supra note 9, at 1921-36. For other discussions of surrogacy and related issues, see LORI ANDREWS, BETWEEN STRANGERS: SURRogate MotHERS, EXPECTANT Fathers, \& Brave New Babies (1989); Martha A. Field, Surrogate MotherhoOd (1988); SuRrogate Motherhood: Politics AND Privacy (Larry Gostin ed., 1990). 
participants in a market for reproduction. Furthermore, some may object that both surrogacy and prostitution undermine the traditional conception of a woman's role and her place within the family. ${ }^{119}$ Indeed, within the larger social context, surrogacy could transform the character of the family itself. ${ }^{120}$ These concerns are all animated by a fear that commodification threatens established gender roles and social structures that many perceive to be natural and right in themselves.

While these two sets of concerns are not necessarily mutually exclusive, they are very different in tenor. They reflect differing visions of gender roles, the structure of the family, and the appropriateness of conscious attempts to control human biology. The first set of concerns echoes feminist, and to some extent, liberal views regarding inequality and subordination. The second set of concerns stems from the largely right-wing "traditionalist" perspective that has marked the right-to-life movement. ${ }^{121}$ However one labels these concerns, the point remains clear: Even when there appears to be a consensus on the surface, pervasive disputes exist not too far underneathnot only between feminists and traditionalists, but among each group's members as well. ${ }^{122}$

Focusing on these divergent perspectives would be more productive than speaking of some supposed consensus favoring "nonmonetized equal sharing" or disfavoring the treatment of our bodies as sources of fungible parts.

119. Nadine Taub suggests that some attacks on surrogacy stem from a fear that women's traditional virtues will be compromised:

There is something suspicious about a society's sudden and vociferous concern with payment now that women propose to take compensation. I wonder whether people fear that rewarding the reproductive functions of a woman will separate them from her overall identity. The concern seems not to be that payment necessarily precludes dignity, but perhaps that a woman's special quality depends on her role as gestator and nurturer.

Nadine Taub, Surrogacy: Sorting Through the Alternatives, 4 BERKELEY WOMEN's L.J. 285, 294 (1989-1990).

120. One commentator suggests that surrogacy threatens to blur the sharp distinction that traditionalists draw between "the individualist world of economic interest and an idealized world of affective relations [that] are supposed to exist within the family structure." Thomas C. Shevory, Rethinking Public and Private Life via the Surrogacy Contract, 8 PoL. \& THE LIFE SCI. 173, 182 (1990). Surrogacy arrangements could help break down this distinction, he argues, by "encourag[ing] sacrifice and altruism beyond the carefully delimited sphere of family life, where it is generally confined in liberal societies." Id.

121. These differing perspectives are likely to have implications for a range of related issues. For example, those who fear that prostitution undermines the traditional family may be far less likely to support comparable worth legislation than those who object to prostitution on the grounds that it embodies and supports men's power over women's bodies. Similarly, someone primarily concerned with equality might have fewer qualms about in vitro fertilization than one who worries about violating natural imperatives or religious commands. Feminist concerns about in vitro fertilization are likely to go less to the question of whether people are arrogating to themselves god-like powers and more to the prospect that women who undergo that procedure will be subjected even more intensely to the strictures of sexism. See, e.g., Gena Corea, The New Reproductive Technologies, in The Sexual Liberais and the ATtack on Feminssm 85, 92 (Dorchen Leidholdt \& Janice G. Raymond eds., 1990) [hereinafter ATTACK ON FEMINISM] (discussing European feminists' concerns that in vitro fertilization may "reduce women to breeders"); see also Radin, Market-Inalienability, supra note 9, at 1930-32 (arguing that medical solutions to infertility emphasize the genetic aspects of parenthood and may thereby reinforce patriarchy).

122. For a fuller account of these tensions, see Schnably, supra note 99, at 766-75. 
Although Radin's analysis of commodification is informed by a feminist sensibility that gives it a richness that few other discussions of those issues match, it seems odd to present that sensibility or vision as a set of deeply embedded social values, precisely at the time when a key element of the feminist project-securing women's reproductive rights-is under massive assault. Any attempt to tie Radin's position to some general consensus will, at best, lend the analysis an air of unreality.

Thus, both the conflict surrounding the traditional home and the tensions underlying opposition to commodification of the body illustrate the elusiveness of consensus. The moment we go beyond any extreme levels of generality about the home, the air of consensus disappears both as a description and as a source of prescription. Similarly, a sustained analysis of our ideals regarding the body and sexuality reveals deep disagreements about human flourishing. In short, a focus on consensus simply cannot deliver what it promises: a relatively uncontroversial basis for legal rules and decisionmaking.

\section{The impossibility of bracketing consensus.}

In bracketing certain aspects of the vision of human flourishing, Radin effectively assumes that the application of particular consensual norms of personhood does not significantly affect those norms. This position, too, is untenable.

Radin's theory of personhood appears to envisage a pre-contextual self and a contextual self. The pre-contextual self first exists in a world of things external to itself, none of which has any particular meaning for it. The contextual self is created only as the self becomes embodied in part of the external world, binding the self's personhood with that aspect of the world; as a result, that aspect of the external world takes on meaning for the self. ${ }^{123}$

Because the concept of pre-contextual selves is purely theoretical and clearly unrealistic, the real weight of Radin's description of personhood is carried by the assumption that the self is always contextual. ${ }^{124}$ Although we may embody ourselves in new and different things or give away or dispose of things to which we were previously attached, we always begin as contextualized beings. This observation has an important consequence for the possibility of bracketing consensus: Given that we are contextualized, the investment of our personhood is necessarily influenced by our circumstances and surroundings. At base, if I am to be confident that something is mine, others must acknowledge my claim. Only the security of that recognition allows me to see my personhood as bound up with that object. Because my embodiment thus depends in part on others' acquiescence, their approval or disapproval will influence my desires and goals. ${ }^{125}$ In short, what we as a

123. See Radin, Personhood, supra note 16, at 971-78 (giving an account of Hegel's theory of property).

124. See Radin, Market-Inalienability, supra note 9, at 1904-06; Radin, Personhood, supra note 16 , at 959-61, 977-78 (discussing the context lent to the self through personal property).

125. Social condemnation might even strengthen one's commitment to embody oneself in a 
society choose to recognize and protect as personal inevitably affects subsequent choices by individuals of how and where to embody themselves. ${ }^{126}$

This evaluation of Radin's theory of self-embodiment suggests that even in its most prototypically private guise-one person "involving herself" in her home-the process must be profoundly social. By showing that individual embodiment is supported by powerful structural factors, a sociological critique of Radin's approach to the home indicates that we could never simply apply any given ideal. Yet for all her invocation of consensual values, Radin says remarkably little about the social and political issues that might clarify how and why people invest their personhood in property.

We might begin to fill this gap with a basic question: Why do so many people tend to identify with their homes? The assertion that this identification is healthy reflects, in large part, the structural factors that make the home and family life appear to be a "haven in a heartless world."127 Behind this popular sentiment lies an implicit acknowledgement of the fragmentation, degradation, and powerlessness that confront many people at work and in other aspects of public life. To the extent that society fosters an environment that affords special personhood protection to the home rather than to the workplace, people will be more likely to view the home as the locus of their personal development. ${ }^{128}$

Structural factors also account for the particular characteristics of the ideal of the home mentioned earlier-its tendency to lack diversity, its identification with domestic gender roles, and its emphasis on private solutions to public problems. To begin with, the rapid growth of suburbs in the postWar era was not only a reflection of people's tastes, but was also a result of significant federal assistance. ${ }^{129}$ The suburbs' homogeneity, consciously en-

particular way. Whatever the reaction, society's judgment almost certainly has an effect. One never has a direct relation to the external world; its meaning for any individual is always socially mediated. For a useful discussion of the effect of existing distributions of power and wealth on preferences, see Cass R. Sunstein, Legal Interference with Private Preferences, 53 U. CHI. L. Rev. 1129, 1145-58 (1986).

126. At some very general level, Radin would recognize this fact. She remarks that "every application of [rules] is a reinterpretation.... [E] ach time we feel ourselves to be rule-followers we are rule-creators as well." Radin, Rule of Law, supra note 3, at 819; see also SIDNEY W. MiNTZ, SWeetness and Power: The Place of Sugar IN Modern History 157 (1985):

We are able to perceive and interpret the world only in terms of pre-existing, culturespecific systems for endowing reality with meaning. This perspective puts the cognitive order between us and the world itself - we must think the world to be able to see (classify) it, rather than the other way round-and it should be persuasive for anyone who considers culture as the prime defining feature of human uniqueness.

However, Radin does not explore the implications of this observation in a systematic way.

127. See generally Christopher LASCH, HAVEN IN A HEARTLESS WORLD: THE Family Besieged (1977).

128. For a more extensive discussion of the relationship between consumer culture and the degradation of work, see notes 180-236 infra and accompanying text.

129. See JACKSON, supra note 98, at 190-218; Brian J. O'Connell, The Federal Role in the Suburban Boom, in Suburbia RE-EXAMINEd 183 (Barbara M. Kelly ed., 1989). For a description of the role of the Federal Housing Administration in planning the course of residential development, see MARC A. Weiss, The Rise OF the Community Builders: The AMERICAN REAL Estate INDUSTRY AND URBAN LAND PLANNING 141-58 (1987). Indeed, no pattern of land use is totally unplanned; the only question is whether the planning will be subject to public controls. See Robert 
couraged by federal subsidies until the $1960 \mathrm{~s}, 130$ instantiated the racial and economic inequalities that have characterized our society (and still do). Further, the social choice in favor of the automobile was attributable not only to the influence of the suburban home as an ideal, but also to the influence of "private" actors with significant social power, ${ }^{131}$ and to the federal government's decision to subsidize road-building to a far greater extent than public transportation. ${ }^{132}$

Nor are the gender roles associated with the traditional family somehow natural or spontaneous creations. As feminists have noted, the family is in important senses a creation of the law, which has given powerful support to men's authority within the home. ${ }^{133}$ And surely many women's embrace of the domestic roles traditionally accorded them had much to do with their exclusion from the workplace or confinement to lower-paying jobs.

My point is not that the ideal of the home has been imposed on hapless victims. Rather, I wish to emphasize that if we accept the theoretical observation that individual embodiment is always socially mediated, we must engage in an analysis quite different from Radin's. The ideal of the home is not one simply constructed by individuals, but is one that has been actively fostered by the state and other "private" actors wielding significant social

Fisher, The Urban Sunbelt in Comparative Perspective: Houston in Context, in Essays on SUNBELT CtTIES AND Recent URBAN AMERICA 33, 40, 47 (Robert B. Fairbanks \& Kathleen Underwood eds., 1990).

130. See JACKson, supra note 98, at 197-218; WRIGHT, supra note 101, at 247-48. For an insightful analysis of the role of the government in promoting segregation in housing, and the measures that would be needed to counter the effects of that role, see Martha Mahoney, Note, Law and Racial Geography: Public Housing and the Economy in New Orleans, 42 STAN. L. REV, 1251 (1990).

131. The charge that the "Big Three" automobile companies conspired to eliminate public rail transit is well known, thanks to hearings held before a Senate subcommittee in 1974. See Hearings on S. 1167 Before the Subcomm. on Antitrust and Monopoly of the Senate Comm. on the Judiciary, 93d Cong., 2d Sess. $1839-70$ (1974) (statement of Bradford C. Snell); see also David J. ST. Clarr, THE MotoRizATION OF AMERICAN Crries 171-78 (1986) (expounding more nuanced version of "social entrepreneurship"); GleNN YaGo, ThE DECLINE OF TRANSIT: URBaN TRANSPORTATION IN GERMAN AND U.S. CITIES, 1900-1970, at 49-76 (1984) (discussing the formation of U.S. national transportation policy). For a critique of Snell's and St. Clair's arguments, see DoNald FINLAY Davis, Conspicuous Production: Automobiles and Elites in DeTroit, 1899-1933, at 15976 (1988).

132. For a discussion of the role of federal policies in the rise of the suburbs in the post-War era, see King Cushman, Exploring the Land Development and Transit Connection, in TRANSIr, LAND USE \& URBAN ForM 9, 18-23 (Wayne Attoe ed., 1988).

133. Martha Minow argues that the family was never unaffected by the law:

Rather than marking a boundary limiting state intervention in the family, laws governing the family define the kinds of families the state approves. The state once authorized the male head of household to discipline his wife and children; later practices that refused police protection for family members victimized by the husband established the kind of behavior the law tolerated. Given background social practices, a policy of "nonintervention" by the state bolstered the authority of the man. State-created rules about what counts as a criminal assault regulate the family, determining, for example, whether the state recognizes or refuses to recognize marital rape as "real rape," which can trigger the criminal justice enforcement apparatus. Similarly, the laws governing who may marry, as well as who may divorce, put the power of the state behind some agreements and not others. More recently, adult and minor women have secured the legal right to obtain an abortion free from the interference of other family members.

MiNow, supra note 98, at 276-77. 
power. Each decision to protect a personal interest necessarily reinforces the ideal. Thus, those decisions can never be justified on the ground that we all agree that the personal interests at issue should be protected; the question always remains, should we further bolster the ideal by protecting it, or should we think about fostering alternatives?

Thus, consensus cannot provide a guide to resolution of legal issues because there is no consensus in any meaningful sense. The moment we attempt to identify a value as consensual, we engage in a practice that makes it all too easy for exercises of power to remain hidden. Moreover, since the law itself often shapes consensus, purporting to rely on consensus to shape the law is a dangerous exercise in circularity. In attempting merely to apply a given consensus, we necessarily strengthen it as well. ${ }^{134}$

My criticism is not that Radin's approach absolutely prevents us from being aware that power is exercised over people, affecting their beliefs. Rather, my objection is that her theory consistently tends to divert attention from this reality. An analogy may be useful: A practitioner of law and economics in theory may take account of costs that are hard to value in dollar terms, but the law and economics approach makes them easy to ignore. ${ }^{135}$ Similarly, nothing prevents one following Radin's approach from recognizing that any given social consensus is deeply influenced by power. By pro-

134. Thus, regardless of the merits of Radin's particular conclusions, her reliance on consensus obscures important issues. For example, Radin cites Stanley v. Georgia, 394 U.S. 557, 565 (1969) (holding that the First Amendment prohibits a state from convicting someone for possessing pornography in his home), to support her claim that a social consensus supports the home as "afirmatively part of oneself-property for personhood-and not just the agreed-on locale for protection from outside interference." Radin, Personhood, supra note 16, at 991-92. To view Stanley as a relatively straightforward outgrowth of consensus in favor of the home is too simple. If we thought more concretely about the issue, we might consider the feminist concern that pornography not only depersonalizes women, but also fosters red light districts, encourages violence against women, and bolsters attitudes that promote sexual harassment at the workplace. See, e.g., MACKINNON, supra note 4, at 183-84; Caryn Jacobs, Patterns of Violence: A Feminist Perspective on the Regulation of Pornography, 7 Harv. WOMEN's L.J. 5, 18-23 (1984); Cass R. Sunstein, Pornography and the First Amendment, 1986 Duke L.J. 589, 591-602; see also CATHARINE MACKINNON, TOWARD a FeMINIST TheORY OF THE STATE 196-97 (1989) [hereinafter MACKINNON, FEMINIST ThEORY OF THE STATE] (stating that from a feminist perspective, pornography "with the rape and prostitution in which it participates, institutionalizes the sexuality of male supremacy, which fuses the erotization of dominance and submission with the social construction of male and female"). The search for consensus too easily leads us to ignore those concerns. Moreover, the image of staying the hand of the state to respect some consensual ideal fits all too easily with an image of nonintervention into private life that, as feminists have made clear, obscures the constitutive nature of the state's power.

My aim is not necessarily to decry Stanley's outcome, but to argue that any consideration of the issue ought to highlight tensions within the ideal of the home, and address the question of what sort of state "interventions" would best resolve them. These are far more deeply contested and difficult political issues than a focus on social consensus suggests. Given the importance of context to Radin's theory, her failure to analyze the actual social context of pornography is striking. Ironically, the "texture of the human world," which Radin notes is damaged by law and economics talk about the marginal value of rape to rapists-even if that talk is proffered in support of statutes criminalizing rape, Radin, Market-Inalienability, supra note 9, at 1881-85 (citing HILARY PUTNAM, REASON, TRUTH AND HISTORY 141 (1981)) -is equally damaged by the straightforward invocation of personhood in support of Stanley.

135. See Radin, Market-Inalienability, supra note 9, at 1878 (noting that law and economics theoretically could take nonmonetizable values into account but in fact often fails to). 
viding no conceptual tools for incorporating that recognition into its methodology, however, her approach makes it easy to overlook that fact.

\section{The first heuristic.}

The first heuristic aims to supply the missing conceptual tools that will allow Radin's theory to account for the power relations that help shape societal consensus. This heuristic prompts us to examine the tensions underlying a supposedly consensual value and to consider the power relations that were instrumental in creating it. ${ }^{136}$ In this section, I will show that a focus on the tensions associated with the home would better contribute to the debate over homelessness than would an emphasis on a supposedly shared agreement on the importance of personal embodiment in the home. The "consensual" values we hold may in fact underlie policies that compound a serious social problem in the first place.

Radin's invocation of the home as a shared ideal raises an interesting question: What might her work tell us about people who have no homes? Although Radin herself does not address this issue, ${ }^{137}$ her analysis has significant implications for the problem of homelessness. The seemingly uncontroversial assertion that "personal embodiment in the home is good" might seem to support two conclusions. First, home-like relationships to property or places are entitled to heightened respect, similar to that which we accord homes; ${ }^{138}$ perhaps we should treat nonconventional living spaces, for example, the area under a bridge, as homes, at least for Fourth Amendment purposes. ${ }^{139}$

The second and more sweeping assertion that might be derived from $\mathrm{Ra}$ din's approach is that people should have homes-or at least, should not be deprived of the opportunity to have them due to circumstances beyond their control. ${ }^{140}$ Perhaps, then, we should recognize a personal stake in access to

136. This heuristic has undergirded my critique of reliance on consensus in the context of the ideals of embodiment in the home and of bodily integrity.

137. For a useful discussion of personality theory and the homeless, see Rosendorf, supra note 10, at 710-12. For background on the extent of homelessness, see MARTHA R. BURT, OVER THE EDGE: THe Growth OF HoMELESSNESS IN THE 1980s, at 11-30 (1992); Carol L.M. Caton, The Epidemiology of Homelessness, in HOMELESS IN AMERICA 19, 22-29 (Carol L.M. Caton ed., 1990); White, supra note 108, at 275-79.

138. Radin rejects any suggestion that the homeless should be deprived of the personhood protections that our society normally associates with having a home:

I do not mean to suggest that one must have property or a home to be a person at all.

The homeless are surely persons. The argument here might suggest that by virtue of their

personhood they are owed homes, not that our failure to ensure that they have homes

renders them non-persons beyond our concern.

Radin, Rent Control, supra note 20, at 365.

139. In State v. Mooney, 218 Conn. 85, 111-12, 588 A.2d 145, 160-61, cert. denied, $112 \mathrm{~S}$. Ct. 330 (1991), the Connecticut Supreme Court held that a homeless person suspected of murder had a reasonable expectation of privacy in a duffel bag and cardboard box that he kept stowed away under a bridge where he regularly slept. Without directly ruling that it should be treated as his home, the court gave great weight to Mooney's treatment of the area as such, and invalidated the warrantless search of the duffel bag and cardboard box. Id.

140. See Radin, Personhood, supra note 16, at 990 ("If the personhood dichotomy in property is taken as the source of a distributive mandate as part of ... a general theory [of welfare rights or 
vacant residential buildings under some circumstances, 141 or create "safe zones" in which those lacking homes can carry on the daily activities of life without fear of arrest. ${ }^{142}$ Aside from the many ways in which having a home makes full personhood possible in our society, the denial of housing to homeless people when residential buildings remain vacant and boarded up dramatically instantiates society's indifference to their fate.

Despite its potential attractions, however, such an analysis seems seriously inadequate. To put it as bluntly as possible, do we really want homeless people to have "homes?" We can ask this question without asserting that the homeless are somehow entirely different in their aspirations from everyone else, or simply less deserving. ${ }^{143} \mathrm{My}$ point is that in deciding what to do about the problem of people who lack homes, we ought to think critically about the traditional idea of the home as a private enclave, grounded in racial and economic exclusion and in the degradation of public space. Precisely because the ideal is a deeply contested one, it would be strange to think that the long-term solution to homelessness should be the opportunity for everyone to buy into the suburbs. ${ }^{144}$

Proceeding as if there were some relatively neutral or uncontroversial agreement on the value of personal embodiment in the home not only is inaccurate, but also reinforces many of the values that promote the problem of homelessness in the first place. For example, uncritical acceptance of the aspect of the ideal that glorifies personal choice may promote the idea that it is the homeless' choice to live as they do. ${ }^{145}$ This kind of attitude may un-

minimal entitlement], it would suggest that government should make it possible for all citizens to have whatever property is necessary for personhood."). Extrapolating from Radin's remarks about warrantless searches of cars, the argument for this proposition would be that "private enclaves are needed for personhood to develop and flourish, and ... our society is now one in which many people's homes are not that sort of enclave"; consequently, a "liberal government that must respect personhood" should "make it possible for people to treat" certain open areas like their homes. Id. at 1001 .

141. See DukeminIER \& KRIER, supra note 10, at 106-08; Margaret Jane Radin, Time, Possession, and Alienation, 64 WASH. U. L.Q. 739, 745-47 (1986); Rosendorf, supra note 10, at 722-26; Steven L. Winter, Foreword: On Building Houses, 69 TEx. L. REv. 1595, 1624-25 (1991); Ann Mariano, Advocates Stand Up for Poor, Homeless; Campaign to Move Families into HUD Properties Takes Hold in D.C., WASH. POST, Sept. 22, 1990, at E1 (describing squatters' campaign to force federal government to turn over empty federal property to homeless); Chuck Taylor, Police Clear Building, Homeless Evicted; 4-Day Occupation of Building Kindles Ideas on Housing, SEATTLE TIMES, May 24, 1991, at Cl; Rudolph Unger, Trespassing Charges Dropped Against Homeless Activists, CHI. TRIB., Aug. 18, 1988, § 2, at 4.

142. See Pottinger v. City of Miami, No. 88-2406, slip op. at 77 (S.D. Fla. Nov. 16, 1992).

143. Thus, I do not mean to question the need for shelter, or to assert that the homeless should accept as the ultimate solution to the housing shortage the dangerous, underfunded, and overcrowded shelters to which society seems all too willing to relegate them. See Carol L.M. Caton, Crisis Shelter and Housing Programs, in HOMELESS IN AMERICA, supra note 137, at 110, 114-15; Gregory L. Evans, Federal Emergency Shelter Assistance to the Homeless: Mandating a Standard of Decency, 4 Notre Dame J.L. Ethics \& Pub. Pol'y 325, 325-26 (1989); Celia W. Dugger, Big Shelters Hold Terrors for the Mentally Ill, N.Y. TIMEs, Jan. 12, 1992, at A1; Thomas Morgan, Fear and Dependency Jostle in Shelters, N.Y. TIMES, Nov. 4, 1991, at A1.

144. See notes 85-110 supra and accompanying text.

145. President Ronald Reagan remarked that even in "the best of times," the United States has been beset by the problem of "the homeless who are homeless, you might say, by choice." Juan Williams, Homeless Choose to Be, Reagan Says, WASH. Post, Feb. 1, 1984, at A1. Similarly, then- 
dermine society's commitment to help the homeless by encouraging us to overlook the social circumstances that lead to homelessness.

There are, however, many more concrete ways in which uncritical acceptance of the ideal of the home obscures the sources of the problem. Unreflective support of the ideal underlies a housing policy that subsidizes middle-class housing through the tax system, ${ }^{146}$ while at the same time cutting back on housing subsidies that would benefit the poor. ${ }^{147}$ The resulting social investment in middle-class homes reinforces and entrenches the suburban ideal. ${ }^{148}$ It is a simplification, but a revealing one, to say that the ideal of the home and homelessness are two sides of the same coin. ${ }^{149}$

Another tension that affects our treatment of homelessness is the enclave consciousness that is an offshoot of our ideal of the home and community.

White House counselor Edwin Meese III once claimed that people went to soup kitchens because it was cheaper than buying food. See David Hoffman, Discussing Hunger in U.S., Meese Sparks a Firestorm, WASH. PoST, Dec. 10, 1983, at A1.

146. See Michael H. Lang, Homelessness Amid Affluence: Structure and ParaDOX IN THE AMERICAN PolITICAL ECONOMY 84-86 (1989); Todd Swanstrom, No Room at the Inn: Housing Policy and the Homeless, 35 WASH. U. J. URB. \& CoNTEMP. L. 81, $88-90$ (1989).

147. For analyses of the trade-off between middle-class mortgage subsidies and support for low-income housing, see ANN BRADEN JoHNSON, OUT OF BEDLAM: THE TRUTH ABOUT DEINSTITUTIONALIZATION 137-38 (1990); LANG, supra note 146, at 67-93; M.H. Hoeflich \& John E. Thies, Rethinking American Housing Policy: Defederalizing Subsidized Housing, 1987 U. ILL. L. REv. 629, 630-31; Peter Marcuse, Homelessness and Housing Policy, in HoMeless IN AMERICA, supra note 137, at 138; Swanstrom, supra note 146, at 81. The drastic cutbacks in federal support for lowincome housing in the 1980 s were part of a broader right-wing attack on any spending to alleviate poverty. See generally Fred Block, Richard A. Cloward, Barbara EHRENREICH \& Frances Fox Piven, The Mean Season: The Attack on the Welfare State (1987); Frances FoX PIVEn \& Richard A. Cloward, The New Class War: Reagan's AtTack on the Welfare STATE AND ITS CONSEQUENCES (1982).

148. See notes 129-133 supra and accompanying text.

149. Related to the failure to provide adequate housing subsidies for the poor is the failure to provide adequate support for community living by the mentally ill who have been deinstitutionalized. To be sure, there is great controversy over the extent to which deinstitutionalization has contributed to the rise of homelessness. Compare JoHNSON, supra note 147, at 134-57 (stating that the homelessness of the mentally ill is primarily caused by welfare, housing, and unemployment policies) with E. Fuller TorRey, Nowhere to Go: THE TRAGic OdYSSEY OF THE HOMELESS MeNTALLY ILL 138-42, 203-04 (1988) (arguing that deinstitutionalization of the mentally ill is a major cause of the homeless problem). See also Paula F. Eagle \& Carol L.M. Caton, Homelessness and Mental Illness, in HOMELESS IN AMERICA, supra note 137, at 59, $70-72$ (citing both deinstitutionalization and "an acute shortage" of "structured supportive housing arrangements" as causes of the homeless problem).

Regardless of the importance of deinstitutionalization as a cause of homelessness, two things are certain. First, blaming homelessness in general on deinstitutionalization is a convenient way to avoid dealing with the real contribution that cut-backs in the safety net have made. Significantly, homelessness in past years appears to have meant having only enough money to sleep in skid row hotels, not being condemned to the streets. See BuRT, supra note 137, at 108-09, 117-23; see also JOHNSON, supra note 147, at 149-50 ("The mentally ill, like the children of poverty, are among the people most likely to become homeless. To have stretched this simple fact into a causal relationship has ... encouraged all of us to avoid looking at the serious weaknesses in our larger housing and welfare policies."); Marcuse, supra note 147, at 152-53 (noting the tendency to blame homelessness on "personality disorders" without even mentioning the housing shortage). Second, attempts to provide the mentally ill with halfway houses or other forms of community living are often met with near-hysterical opposition by many homeowners in the neighborhood of the proposed facility. See Caton, supra note 143, at 133-34. Such opposition stems in no small part from the extent to which people identify their own personhood with their homes, and instinctively question the personhood of those who do not have homes. See notes 150-151 infra and accompanying text. 
For many, pursuing this ideal means staking a significant portion of their wealth in it, rendering people constantly on guard against any conceivable threat to property values. Those who possess homes come to view their ownership of, and attachment to, their houses as normal. One who does not have a home must, therefore, be abnormal, and possibly even dangerous. ${ }^{150}$ Thus, there is a powerful tendency to confine homeless shelters, as well as low-income housing generally, to enclaves in inner cities. Attempts to locate them in upper middle-class urban areas or in the suburbs typically meet with lawsuits and extreme opposition. ${ }^{151}$ The result of this tendency is that both long- and short-term efforts to meet housing needs for the homeless are likely to reflect the racial and economic exclusion that permeates the ideal of the home. ${ }^{152}$

Finally, when the home becomes a haven or refuge, privacy can easily mean invisibility; ${ }^{153}$ and the distance from the private home to the invisible homeless is not great. Typically, anti-homeless legislation aims to keep the homeless out of public view or out of public spaces. ${ }^{154}$ Kreimer v. Bureau of

150. See Wolfgang Fach \& Anne Hodgson, Common Sense: the Demand Side, the Supply Side, and the Far Side, Telos, Number 86, Winter 1990-91, at 3, 21 (arguing that the homeless "are transformed into habitual offenders, 'delinquents,' who can be stigmatized reliably and who in that way (unwillingly, of course) reconfirm the normality of their benefactors"). On the long history of labeling the homeless as "troubled-and troublesome-individuals," see Kim Hopper, The Ordeal of Shelter: Continuities and Discontinuities in the Public Response to Homelessness, 4 NOTRE DAME J.L. ETHICs \& PUB. POL'y 301, 311-12 (1989).

151. See LANG, supra note 146, at 176-78 (noting suburban opposition to shelters); Caton, supra note 143, at 133-37; note 143 supra; see also John N. Lozier, Mandy Johnson \& Joan Haynes, Overcoming Troubled Relationships Between Programs and the Community, in UNDER THE SAFETY Net: The Health and Social Welfare of the Homeless in the UnIted States 32 (Philip W. Brickner, Linda Keen Scharer, Barbara A. Conanan, Marianne Savarese \& Brian C. Scanlan eds., 1990) [hereinafter SAFETY NET]; Carl Goldfarb, Homeless Center Proposal in Grove Met by Opposition, Miami HeraId, June 7, 1991, at 3B; $c f$. Nucleus of Chicago Homeowners Ass'n v. Lynn, 524 F.2d 225, 230-32 (7th Cir. 1975) (rejecting plaintiff's' request for the preparation of an environmental impact statement under the National Environmental Policy Act of 1969 to forestall the placement of low-income housing in neighborhood), cert. denied, 424 U.S. 967 (1976).

In turn, the tendency to confine shelters to the poorest and least politically powerful areas leads to tensions between the poor and the homeless. See Celia W. Dugger, Here, Poorest are Resented by the Poor: Longtime Residents See Homeless as Interlopers, N.Y. TIMEs, Nov. 6, 1991, at B1; David Gonzalez \& Celia W. Dugger, A Neighborhood Struggle With Despair, N.Y. TIMEs, Nov. 5, 1991, at A1. This tension helps divide groups that otherwise might have a common cause against right-wing social policies.

152. See generally Katherine C. Devers \& J. Gardner West, Note, Exclusionary Zoning and Its Effect on Housing Opportunities for the Homeless, 4 Notre Dame J.L. ETHICS \& PUB. PoL'y 349 (1989).

153. Thus, "the family can be-and often is-the locus of violence and sexual abuse, hidden from view all the more effectively because it is deemed private." T.A. Tucker Ronzetti, Comment, Constituting Family and Death Through the Struggle with State Power: Cruzan v. Director, Missouri Department of Health, 46 U. MIAMI L. REV. 149, 174-175 (1991).

154. See Sara Rimer, Doors Closing as Mood on the Homeless Sours, N.Y. TIMEs, Nov. 18, 1989, at A1. In Miami, the police in the past have used misdemeanor ordinances, such as nuisance and littering laws, to arrest homeless persons prior to events such as the Orange Bowl Parade and the 1987 visit by Pope John Paul II "to force the homeless off the streets and out of sight." Carlos Harrison, $A C L U$ to Miami: Stop Harassing Homeless, Miami Herald, Dec. 30, 1988, at 1D; see also Pottinger v. City of Miami, 720 F. Supp. 955, 957 (S.D. Fla. 1989) (certifying a class of approximately 5000 homeless people to bring suit against the city of Miami for violating their constitutional rights); Donald E. Baker, Comment, "Anti-Homeless" Legislation: Unconstitutional Efforts to Punish 
Police, ${ }^{155}$ a case that attracted nationwide attention, ${ }^{156}$ concerned one town's ultimately successful effort to keep the homeless out of its public library. ${ }^{157}$ People should do their living in private, not in full view of everyone; that is the spirit of many anti-homeless laws, and it fits all too comfortably with the valorization of the private home as the exclusive area of personal growth and development.

In short, applying "consensus" in favor of the home will not yield solutions to the problem of homelessness. By directing our attention to what is most problematic about the home as an ideal, the first heuristic helps us see the ways in which any existing social consensus reflects power relations, and therefore is subject to change in the event of a shift in those power relations. As a result, this approach is likely to produce more powerful insights into the origin of homelessness and its possible solutions.

\section{B. Commodification as Absolute Power}

While Radin tends to disregard the exercise of power in shaping consensus, she also, paradoxically, treats power as completely dispositive. In Radin's conception, commodification utterly disempowers people; the only solution is for the state to counter commodification by imposing rules of market-inalienability. This conception of commodification ignores the potential for resistance. For all Radin's concern for personhood, her theory views individuals as the passive beneficiaries of a personhood-respecting state.

The problem with such an account is that it depicts an essentially static society-a society in which the sources of change remain hidden and obscure. Radin's failure to examine consensus critically or to address the effects of power in the shaping of consensus gives her theory an implicit conservative bias.

The problem can be restated in Radin's terminology. Treating people as passive objects renders the double bind pervasive and unresolvable. If commodification leaves people as utterly disempowered as Radin's treatment im-

the Homeless, 45 U. MTAMI L. REv. 417, 419 (1990-1991) (describing a "clash of competing interests between homeless persons' exigency to perform fundamental life activities in public, and nonhomeless citizens' desire to be able to utilize freely public facilities without encountering 'unsightly' homeless people"); $c f$. Isabel Wilkerson, Shift in Feelings on the Homeless: Empathy Turns Into Frustration, N.Y. TIMES, Sept. 2, 1991, at A1 (noting trend to enact "harsher restrictions on homeless people to reduce their visibility" or force them to leave town). $I I)$.

155. 765 F. Supp. 181 (D.N.J. 1991) (Kreimer I), rev'd, 958 F.2d 1242 (3d Cir. 1992) (Kreimer

156. See, e.g., David Ellis, Star of His Own Sad Comedy, TIME, Mar. 9, 1992, at 62-63.

157. Granted, the ordinance did not exclude the homeless per se, but rather permitted library officials to ban anyone whose "bodily hygiene" was "offensive." Kreimer I, 765 F. Supp. at 184 . The Third Circuit reversed the district court's ruling that the statute was unconstitutional and held that because the "homeless do not constitute a suspect class," only a rational basis standard of review would apply. Kreimer II, 958 F.2d at 1269 n.36. Still, it is difficult to see this ordinance as anything other than an effort to deal with the problem of homelessness by keeping it out of sight. Cf. Kreimer $I, 765$ F. Supp. at 183 ("If we wish to shield our eyes and noses from the homeless, we should revoke their condition, not their library cards."). 
plies, then the only way to promote decommodification is for the state to disable people by stripping them of the right to sell some relevant attribute. Alternatively, the state could partially decommodify them by partially disabling them-that is, by limiting the terms under which they may sell that attribute. Any measure that advances partial or complete decommodification will be vulnerable to the charge that it disrespects the very objects of its protection by prohibiting them from entering into a market transaction to which they would otherwise agree.

\section{The tendency toward stasis.}

Examples of the tendency. The relatively static character of Radin's analysis has two manifestations. The first is a bias toward the status quo that results from her efforts to glean from existing case law evidence confirming society's adoption of consensual values. The second manifestation is Radin's apparent inability to relate her nonideal evaluations to some broader program of social change.

As one example of social confirmation of consensus, Radin finds support in a wide variety of legal doctrines for the personhood interest in the home. For example, she points to anti-eviction provisions found in rent control legislation as an indication that society recognizes this interest, at least implicitly. ${ }^{158}$ This assertion, however, is fundamentally flawed: The vast majority of lower-income people who live in apartments are not protected by antieviction and rent control laws. ${ }^{159}$ With so little housing thus protected, it seems unlikely that rent control reflects a consensus on the importance of the home. Indeed, rent control is constantly under attack from the right, ${ }^{160}$ and even when local governments invoke "protective" legislation like housing codes, they may sometimes do so as a ploy to rid the locality of people of color or those with lower incomes. ${ }^{161}$ By treating tenant-protective legisla-

158. See Radin, Rent Control, supra note 20, at 372.

159. Although there are no definitive statistics, it is clear that rent control covers only a small minority of housing in the United States. See Kenneth K. Baar, Guidelines for Drafting Rent Control Laws: Lessons of a Decade, 35 RuTGERS L. REv. 723, 725 n.1 (1983); see also Brief of the National Multi Housing Council as Amicus Curiae in Support of Appellants at 8, Pennell v. San Jose, 485 U.S. 1 (1988) (No. 86-753) (asserting that "[t]oday, approximately 200 communities continue to have some form of rent control. Virtually all are located on the East and West Coasts, where rental units make up an important part of the market."). Granted, market conditions everywhere may not require rent control to protect lower-income tenants; even so, it seems likely that there are large numbers of lower-income tenants who lack needed protection. Moreover, there is little evidence that, where enacted, rent control statutes have in fact brought down rents to levels more affordable to lower-income people, see JoHN I. GILDERBLOOM \& RichaRD P. APPELBaUM, RETHINKING RENTAL Housing 127-49 (1988), which may cast into doubt the strength of any supposed social commitment to a personhood interest in lower-income people's homes.

160. Rent control became a national issue in the late 1980s when the Reagan Administration attempted to discourage localities from adopting it. See Robert Pear, Rent Control is Target of Reagan Budget, N.Y. TIMES, Jan. 8, 1988, at A32 (noting plan in draft budget to cut off federal funds for housing repairs to cities that have rent control); Robert Kuttner, Reagan is Hypocritical on Rent Control, NEWSDAY, Jan. 14, 1988, at 83 (same).

161. See Lisbeth Haas, Grass-Roots Protest and the Politics of Planning: Santa Ana, 1976-88, in Postsuburban California: The Transformation of ORange COUNTY SinCe World War II, at 254, 267-71 (Rob Kling, Spencer Olin \& Mark Poster eds., 1991). 
tion as evidence of consensus, Radin inadvertently runs a great risk of encouraging complacency toward the forces in our society that do not respect long-standing ties of lower-income tenants to their homes and neighborhoods.

Another example of the same approach is Radin's assertion that "collective bargaining, minimum wage requirements, maximum hour limitations, health and safety requirements, unemployment insurance, retirement benefits, prohibition of child labor, and antidiscrimination requirements" can be understood as "an effort to take into account workers' ... personhood, to recognize and foster the nonmarket significance of their work." 162 This account implicitly depicts a gradual and growing social effort to decommodify labor. The history of labor law, however, contradicts this implication; American business has sought relentlessly to reverse the gains obtained by labor through militancy and conflict during the 1930s. Moreover, labor legislation is deeply ambiguous, for it also has played a role in the further commodification of labor by integrating workers into a stabilizing corporate structure that tends to treat them as simple inputs into the production process. ${ }^{163}$ An understanding of labor laws as indicative of widespread social respect for personhood is thus ahistorical and acontextual, explaining little if anything about the origin and current significance of such laws.

In short, Radin's efforts to demonstrate the law's recognition of personhood interests is flawed because she too often overlooks the extent to which society systematically disrespects those interests. The systemic nature of that disrespect calls into question whether those values are consensual at all. Equally important, the search for glimpses of consensual values emerging in the law too easily leads Radin to overlook the struggles that have produced the very glimpses she finds. By projecting an image of a society not subject to struggle and conflict, Radin unfortunately downplays its major source of dynamism. Whenever a theory fails to consider how social changes come about, the danger of a conservative bias comes to the fore.

Radin's discussion of kidney-selling illustrates the second form the potential for conservatism can take: a failure to indicate, even if only tentatively, how to relate particular nonideal evaluations to a more general program of change. She begins with the premise that organ sales harm per-

162. Radin, Market-Inalienability, supra note 9, at 1919-20.

163. See Karl E. Klare, Judicial Deradicalization of the Wagner Act and the Origins of Modern Legal Consciousness, 1937-1941, 62 MINN. L. REV. 265, 268-69 (1978) (arguing that judicial interpretation of the Wagner Act created "the rudiments of what later became an increasingly formalized and regulated institutional structure for the state administration of the class struggle"); Katherine Van Wezel Stone, The Post-War Paradigm in American Labor Law, 90 YALE L.J. 1509, 1517 (1981) (arguing that industrial pluralism in labor law "serves as a vehicle for the manipulation of employee discontent and for the legitimation of existing inequalities of power in the workplace"); $c f$. Klare, supra, at 267 ("[S]ince World War II, organized labor has become more integrated into the economic system of advanced capitalism, progressively more dependent on its erstwhile corporate adversaries, and largely conventional in the political arena."). See generally Christopher L. TOMLINS, ThE STATE AND THE UNIONS: LABOR RELATIONS, LAW, AND THE ORGANIZED LABOR MOVEMENT IN AMERICA, 1880-1960 (1985). 
sonhood and promote an inferior conception of human flourishing. ${ }^{164}$ She then notes the problem posed by the double bind, observing that prohibiting the sale of kidneys may harm people even more. ${ }^{165}$ For example, she fears that prohibiting a parent from selling a kidney to finance surgery needed for a child will only worsen the parent's plight (as well as the child's). ${ }^{166}$

Although Radin acknowledges that this dilemma implicates a broader systemic issue, she provides no guidance for dealing with it. She remarks that situations in which all available choices are inconsistent with preserving personhood show the need for more general social change. ${ }^{167}$ In other words, there is clearly something wrong with a society in which people feel compelled to sell their kidneys. Radin, however, fails to provide any guidance for determining what we should do to move toward a more ideal society. Given that our goal is social change, should we ban or permit kidney sales?

Radin candidly recognizes that she has no answer, remarking, "Obviously, I have no handy algorithm for making this decision."168 Yet such an "algorithm"-or rather, theory-is indispensable to any adequate understanding of personhood. A response to the double bind that does not attempt to relate the particular nonideal solution to a broader effort at social transformation will most likely amount to no more than tinkering or stabilizing reform.

Reasons for the tendency. Radin clearly is aware of the need for a systematic critique. ${ }^{169}$ Thus, her failure to provide one is particularly striking. Evidently, something in her approach consistently renders elusive the formulation of such a critique.

To some extent, Radin's failure to offer any theory of transformative social change may relate to her assumption that the normative questions can be bracketed; as noted, a theory that assumes away conflict over our deepest values downplays any need or possibility for change and thereby helps to entrench the status quo. However, a deeper explanation of the omission may lie in Radin's conception of state power, which implicitly overstates the passivity of individuals.

For the most part, Radin does not portray people seeking, individually or collectively, to transform their lives or society. Rather than focusing on transformative efforts as the key agents of social change, Radin concentrates

164. See Radin, Market Domain, supra note 9, at 169-70.

165. Id. at 169 .

166. See id.

167. See id. at $169-70$.

168. Id. at 188; see also note 16 supra. Indeed, it is not clear she wants to have an algorithm in all cases. See Margaret Jane Radin, Rent Control and Incomplete Commodification: A Rejoinder, 17 PHIL \& PUB. AFF. 80, 83 (1988) (referring to her method as "relatively particularist and nonalgorithmic"); note 3 supra.

169. See, e.g., Radin, Market Domain, supra note 9, at 187 ("If neither commodification nor noncommodification can put to rest our disquiet about harm to personhood in conjunction with certain specific kinds of transactions ... then we must rethink the larger social context in which this dilemma is embedded. We must think about wealth and power redistribution."). 
almost exclusively on the promulgation and implementation of legal rules to respect personhood. That focus ultimately is unilluminating.

Consider again Radin's discussion of rent control. If, as noted earlier, there is little basis for deeming rent control statutes an effective social recognition of personhood, ${ }^{170}$ it does not necessarily follow that they are useless; it only means that the utility of rent control must be described in a context that Radin's analysis fails to address, namely the long history of tenant organizing. ${ }^{171}$ For example, neighborhood activists and legal services lawyers have declared "eviction free zones," using the warranty of habitability and other legal means to resist gentrification. ${ }^{172}$ In addition, movements for rent control have empowered tenants by bringing them together to work on an issue of immediate concern, thereby building a base of support for a variety of other progressive reforms. ${ }^{173}$ Although housing problems cannot be fully addressed at a local level, the forging of a community of people " 'reborn' in a socially conscious and collective manner"174 produces a real benefit, building "self-respect and fighting spirit," 175 facilitating the creation of coalitions with other activist groups, and awakening people to the need for broader systemic change. ${ }^{176}$

These efforts change individuals' personhood and, to some extent, create a new collective personhood as well. These efforts do not constitute a social

170. See notes 158-161 supra and accompanying text.

171. See Allan David Heskin, Tenants and the American Dream: Ideology and THE TENANT MOVEMENT 3-37 (1983).

172. See Lawrence K. Kolodney, Eviction Free Zones: The Economics of Legal Bricolage in the Fight Against Displacement, 18 ForDHAM URB. L.J. 507, 514-20 (1991); see also id. at 543 ("Because gentrification is a process that occurs within a neighborhood, and not just a force imposed from without, neighborhood residents have the ability to alter the course of that process and take some measure of control over their environment.").

173. As two commentators have stated:

When tenants organize for better housing conditions, they learn that simply protesting is not enough to meet their needs. They find that they must involve themselves directly in the electoral system if they wish to see long-term change. A valuable lesson results: Ordinary people, working collectively, can affect [sic] significant change in terms of gaining greater control over the conditions of their lives.... [W] inning one reform can spark demands for even more fundamental changes.

GILDERBLOOM \& APPELBAUM, supra note 159, at 148 (citations omitted); see id. at 144-48 (discussing a successful tenant movement to adopt rent control laws in Santa Monica, California).

174. Tony Schuman, The Agony and the Equity: Strategies for Building Low-Income Housing, in Dilemmas of Activism: Class, Community, and the Politics of local Mobilization 240, 245 (Joseph M. Kling \& Prudence S. Posner eds., 1990).

175. Id. at 253.

176. As Schuman has noted:

Despite its shortcomings, self-help [in building low-income housing] is a currently necessary activity and a useful training ground for local activists. Participants are brought into direct confrontation with market forces and financing schemes. In this sense, it is precisely because self-help does not "work" as a solution that it has potential. The self-respect and fighting spirit of the self-help housers, coupled with their manifest commitment to preserving their neighborhoods, inevitably leads them to defend their physical and emotional investment. As they come to grips with the high cost of housing operation, they are obliged to consider various cost-reducing strategies, including mortgage and tax default. They are also pushed to act in coalition with other self-help groups and to reach out to other lowand moderate-income tenants. 
recognition of personhood interests, with all the passivity that such a characterization implies, but rather a collective forging of personhood. While the new personhood that emerges will not be perfect, or free of its own divisions, its creation is a prerequisite to an effective overall solution to any social problem.

In short, by focusing on how the law may already recognize personhood, Radin shows a relative lack of interest in the question of how rent control statutes come to be enacted. She comes closest to acknowledging the political character of landlord-tenant law when she notes that "the issue of keeping one's home can be seen as inextricably intertwined with the issue of developing and protecting one's political voice."177 She still presents a picture, however, of a disembodied law bestowing the preconditions for community on a group of tenants who would simply be "unable to form strong political communities"178 but for the beneficent intervention of the law. ${ }^{179}$

\section{Commodification in work and personal life.}

Although the tendency to treat people as passive beneficiaries of the law is evident throughout Radin's analysis, her treatment of commodification most clearly displays this tendency. In essence, Radin equates commodification with the existence of a market in which goods and services are bought and sold. ${ }^{180}$ More precisely, she identifies commodification with the legal rules that govern market activity: We are commodified if we are permitted

177. Radin, The Liberal Conception of Property, supra note 3, at 1694.

178. Id. One example Radin offers is the retaliatory eviction defense:

The retaliatory eviction defense ... is rooted in the understanding that if tenants are to be empowered to complain to the authorities about violations of their legal rights, and moreover if they are to be able to organize to enhance their legal status, then loss of their homes as a result of attempted political participation of this kind must be prevented.

Id. (emphasis added).

179. By way of contrast to Radin's approach, consider the work of one theorist of community action who seeks to point "the politics of homeownership" in a progressive direction by "decommodifying" property. JoHN EMmeus DAvis, CONTESTED Ground: Collective ACTION AND THE URBAN NEIGHBORHOOD 322 (1991); see also id. at 317-18 (footnotes omitted):

[C]ommunity organizing and neighborhood planning can strengthen institutions, practices, and rituals that reproduce, within the "cultural terrain" of residential neighborhoods, not the ideologies of capitalist accumulation, but oppositional ideas of property and place. . . . Counted among these "counter-hegemonic elements" are ideas of domestic property that elevate accommodation over accumulation: ideas (and models) that treat housing as a social good instead of a speculative commodity, ideas (and practices) that treat housing as a human right instead of a precarious privilege.

Included, as well, among the "counter-hegemonic elements" of the homeplace are those nonmarket sentiments, practices, and attachments that bind person to person, and person to place.

At one level, Davis' similarity to Radin is remarkable; even his distinction between "accommodative" interests in residential property ("security, amenity, and autonomy") and "accumulative" interests ("equity, liquidity, and legacy"), see id. at 45, calls to mind Radin's distinction between personal and fungible property. However, the central aim of Davis' work is to describe strategies for the building of local organizations and a concomitant development of consciousness, in large part through conflicts over housing issues. In no sense does he assume that decommodification will ever take place simply because the state removes housing (wholly or in part) from the market.

180. See Radin, Market-Inalienability, supra note 9, at 1875 (referring to "alienability" as "the heart of capitalist property relationships"). 
to sell ourselves or some aspect of ourselves; we are decommodified if we are not permitted to engage in such sales; and we are partially decommodified if such sales are permitted to a limited extent (for example, if they are neither criminalized nor given contractual enforcement).

While commodification has something to do with market transfers, it is a mistake to equate commodification with the legality of such transfers. First, a focus on legal rules is unlikely to devote adequate attention to the many ways in which people are commodified independently of the direct power of the law. Second, equating commodification with the legal rules governing market transfers wrongly ignores the possibility of resistance to power, undermining from the outset any effort to look beyond particular issues to broader social change.

A more systemic analysis is possible if we adopt a more comprehensive framework for understanding commodification as a pervasive force in our working lives, as well as in our personal lives. In our working lives, capitalist society is, in a sense, "anti-personhood" because laborers are denied the opportunity to fulfill their self-actuating potential. Contrary to Radin's suggestion, however, legal rules giving employers title to the product of workers' labors and market forces requiring sellers to meet a market price do not impose commodification and alienation on workers. Rather, commodification and alienation result from employers' success in taking control of the labor process by fragmenting and de-skilling labor. The degradation of work has been complemented in our personal lives by the rise of a consumer culture that encourages people to pursue development and self-realization not through work but through the purchase of goods. This culture has reached a point where many consumers come close to defining themselves in terms of the styles and imagery associated with those goods.

An analysis of commodification in these terms has two advantages over Radin's approach. First, when we view commodification as a system, we can grasp more clearly the extent to which commodification already pervades society, apart from the legality of market transfers. ${ }^{181}$ The second advantage, paradoxically, is that this analysis indicates that the commodifying tendency of society, while more pervasive than Radin allows, is not as irresistible as implied by her equation of commodification with the legalization of market transfers.

Commodification as a system of work and consumption. One way to understand what is lacking in Radin's conception of commodification is to scrutinize her discussion of what she calls the Marxian criticism that "under capitalism property itself is anti-personhood." 182 She describes the critique

181. As a result, we can understand why Radin's concern that sex would become commodified if prostitution were legalized has an air of irrelevance: Sex is already pervasively commodified in our culture.

182. Radin, Personhood, supra note 16, at 970 . Roberto Unger has argued that "capitalism" has virtually no explanatory force as a concept; because of the rich historical variations among societies loosely deemed capitalist, every attempt to define the term ends up being either severely overinclusive or underinclusive. See UNGER, supra note 12, at 101-13. Indeed, William Lazonick's 
of the alienation of labor as follows: "Marx portrayed workers' alienation from their own human self-activity as the result of producing objects that became market commodities. By objectifying the labor of the worker, commodities create object-bondage and alienate workers from the natural world in and with which they should constitute themselves by creative interaction."183 Describing fetishism-“a kind of projection of power and action onto commodities"184_-she continues:

Relationships between people are disguised as relationships between commodities, which appear to be governed by abstract market forces. I do not decide what objects to produce, rather "the market" does. Unless there is a demand for paperweights, they will have no market value, and I cannot produce them for sale. Moreover, I do not decide what price to sell them for, "the market" does. At market equilibrium, I cannot charge more nor less than my opportunity costs of production without going out of business. In disequilibrium, my price and profit are still set by "the market"; my price depends upon how many of us are supplying paperweights in relation to how many people want to buy them and what they are willing to pay for them. ${ }^{185}$

Radin's exclusive emphasis on market conduct is misplaced. In Marx's scheme, the treatment of labor power as a commodity to be bought and sold is merely a precondition of alienation. Workers are never, in fact, commodities. Once hired, they must be made to work. The hiring of a laborer is thus the opening of a struggle in which the employer continually tries to wrest effective control of the labor process from the workers. ${ }^{186}$ The extent of commodification depends upon how successful the employer is in this endeavor.

insightful work in comparative economic history shows that the form of work organization I describe in this section is far more characteristic of the American economy than of either the British or Japanese economies. See William Lazonick, Competitive AdVANTAGE on tHE Shop Floor 299-331 (1990). Nothing in Radin's analysis or in my critique of it, however, turns on the assertion that capitalism has some essential characteristic: What is important is the character of work (both blue-collar and white-collar) in our society.

183. Radin, Market-Inalienability, supra note 9, at 1871.

184. Id. at 1872 .

185. Id. at 1873 .

186. In Marxian terms, this struggle arises from the fact that workers sell their "labor power"-their capacity to work-but employers thereby gain rights to the workers' "labor effort." William Lazonick explains the process as follows:

But, Marx asked, if all commodities exchange at their values, what is the source of the surplus value out of which are paid interest, rent, and profits to financiers, landlords, and industrial capitalists? He located the answer in the special position of labor power as a commodity when it enters the capitalist production process. The capitalist gets access to the productive capabilities (labor power) of workers for a wage that will command the amount of labor time socially necessary to reproduce the porker. But labor power is not the same as labor effort. One represents the productive capability of the worker, while the other connotes the actual utilization of that capability in the production process.

The capitalist can try to influence two quantitative dimensions of labor effort: the duration and intensity of work. The first involves lengthening the hours of work, while the second involves increasing the speed of work.

William Lazonick, Business ORganization and the MYth of THE Market Economy 119 (1991). For a good discussion of the limits of Marx's approach, see id. at 120-22. 
In the twentieth century, management has attempted to gain control over the labor process by the continual "Taylorization" or degradation of work. ${ }^{187}$ Through this process, work has become increasingly de-skilled, that is, broken down into repetitive and controllable units. The separation of conception and execution has had a number of consequences, one of which is that for many, work offers fewer and fewer opportunities for creativity. ${ }^{188}$

It would be wrong, however, to focus exclusively on work in discussing commodification. One aspect that Marx neither discussed nor anticipated is the concomitant rise of a consumer culture. An appreciation of the significance of this development is crucial to understanding what "commodification" means in our society. The rise of consumer culture has brought commodification into our personal lives, compounding the effect that Taylorization has wrought in the work place.

A major feature of the development of capitalism in the twentieth century has been the promotion of a tendency to look to leisure and consumption for the meaning and self-fulfillment missing from de-skilled work. ${ }^{189}$ In part, the phenomenon is simply the counterpart to alienation at work. It is therefore wrong to view family life as a previously pristine arena of love and warmth untouched by market relations, because it was created by the same system that gave us the market. Work was taken out of the home, and the home was left to be a refuge-a Belmont to Venice. ${ }^{190}$ The consequent ideal

187. See Harry Braverman, labor and Monopoly Capital: The Degradation of WORK IN THE TWENTIETH CENTURY (1974). On Taylorization, see generally DAN CLAwson, Bureaucracy and the Labor Process: The Transformation OF U.S. INDUSTrY, 1860-1920 (1980); RICHARD EDWARDS, CONTESTED TERRAIN: THE TRANSFORMATION OF THE WORKPLACE In the Twentieth Century (1979). See also Shoshana Zuboff, IN tHe Age of the SMART MACHINE: THE FUTURE OF WORK AND POWER 41-46 (1988) (describing Taylorization and "the purification of effort"). For an evaluation of the role of Taylorism in production in the post-World War II era, see Andrew Glyn, Alan Hughes, Alain Lipietz \& Ajit Singh, The Rise and Fall of the Golden Age, in The Golden Age OF CAPITALISM: REINTERPRETING THE POSTWAR EXPERIENCE 39, 55-56 (Stephen A. Marglin \& Juliet B. Schor eds., 1990).

188. See Braverman, supra note 187, at 113, 124-28; cf. 1 KarL MARX, CAPITAL: A CRITIQUe of Polmical Economy 361 (Frederick Engels ed. \& Samuel Moore \& Edward Aveling trans., International Pub. 1967) ("The knowledge, the judgment, and the will, which, though in ever so small a degree, are practised by the independent peasant or handicraftsman, ... are now required only for the workshop as a whole. ... What is lost by the detail labourers, is concentrated in the capital that employs them.").

Thus, it is inaccurate to say that Marx conceived of alienation per se as "the heart of capitalist property relationships"; it is not merely the fact that the worker must sell his labor power that is key, but that in doing so the stage is set for a contest between capital and labor for control of the work process.

189. See, e.g., Raymond Benton, Jr., Work, Consumption, and the Joyless Consumer, in PhiLoSOPHICAL AND Radical Thought IN MARkeTiNg 235, 245 (A. Fuat Firat, Nikhilesh Dholakia \& Richard P. Bagozzi eds., 1987) (attempting to explain how the pursuit of greater economic activity may actually lead to consumer dissatisfaction and restlessness). One might trace the rise of leisure to the nineteenth century. See generally DaNIEL T. RODGers, THE WORK ETHIC IN INDUSTRIAL AMERICA, 1850-1920 (1974). In any event, consumer culture is a historically specific phenomenon and is not endemic to the human condition.

190. Cf. Roberto Mangabeira Unger, The Critical Legal Studies Movement, 96 HARV. L. Rev. 561, 622 (1983) ("In Venice people make contracts; in Belmont they exchange wedding rings."); id. at 623 ("Each is at once the other's partner and its enemy."). 
of the home, moreover, was a gendered one, intimately bound up with women's role as wife and homemaker and men's role as provider.

The effort to create a mass consumer market has also left its mark on the search for self-fulfillment. The most distinctive feature of this effort is advertising, in which goods, typically in highly gendered forms, are marketed to give the impression of control, status, and mastery. ${ }^{191}$ The imagery associated with cars provides a good example of this phenomenon. More generally, consumer culture is directed at persuading us to seek individually, in the consumption of goods, solutions to social ills. ${ }^{192}$ Consequently, the construction of consumer culture can be understood as a way of enmeshing ourselves in the status quo: Instead of looking to the public sphere and to collective action to remedy social ills, we look to consumption and to personal regimens to give meaning to our lives. ${ }^{193}$

The significance of consumer culture may also implicate our very understanding of ourselves. In his insightful analysis, Stuart Ewen speaks of an emerging conception of the "self as other," marked by an emphasis on assembling a self from commodities and the meanings they symbolize. ${ }^{194}$ Ewen refers to the historical emergence of "style" as a key principle of consumer culture; style, he argues, is "understood as a tool for constructing personhood."195 Embodiment in the home provides an example of Ewen's point: Embodiment may mean buying a collection of Ralph Lauren home furnishings ("furniture, bedding, towels, fabrics and rugs") built around Lauren's "vision of the Safari concept." 196 Investment in that concept is an economical choice for busy selves, for Lauren supplies not only furnishings but a "lifestyle and attitude."197 The shopping mall-the ubiquitous counterpart to the suburban home-provides another example of Ewen's argument. The mall is not simply an agglomeration of stores, but a carefully planned environment designed to create a total experience by which we are expected to define ourselves as consumers. ${ }^{198}$

191. See EwEN, supra note 100 , at 215-17.

192. See Schnably, supra note 99 , at 860 ("For example, if the urban environment was unhealthy or unsafe, the solution was not collective action to improve living conditions, but the purchase of a health or beauty aid or the installation of a better lock on one's door."); $c f$. EwEN, supra note 100, at 103 (noting that "purchasable objects are invested with the connotation of subjectivity").

193. See EwEN, supra note 100, at 103.

194. Id. at 76.

195. Id. at 79. Ewen continues: "Style ... [is] a way of saying who one ... [is], or who one wishe[s] to be. The emerging market in stylized goods [has] provided consumers with a vast palette of symbolic meanings, to be selected and juxtaposed in the assembling of a public self." Id. This conception of style came to fruition with the advent of the American department store, and its successor, the shopping mall.

196. WOMEN'S WeAR DaILY, Apr. 7, 1989, at 9.

197. Id.; see also Patricia Leigh Brown, Lauren's Wink at the Wild Side, N.Y. TIMES, Feb. 8, 1990, at C1, C6 ('Mr. Lauren's lush products for the home [are] 'no risk' items that 'take away the need for decision-making for a lot of people." ") (quoting Professor George Leib of the Fashion Institute of Technology).

198. The rise of the mall was an integral part of the development of consumer culture. Concomitant with the rise of mass advertising in the early part of the twentieth century, retailers began to be concerned with providing something more than goods: 
The attractiveness of assembling an identity this way presupposes the experience of lack of control and creativity associated with the Taylorization of work: "The assembling of a commodity self, this 'dream of wholeness,' implies a sense of partialness and fragmentation that resides just beneath the surface. The appeal of style in twentieth-century cultures cannot be separated from the conditions of the human subject it addresses." 199 The understanding, community, and control that people lose at the workplace are recovered in the meanings that advertising attributes to the consumption of goods. ${ }^{200}$

In sum, consumer culture represents the insinuation of a more detailed form of power into people's lives and self-conceptions. We create ourselves from a palette of alternatives presented to us, encouraged to believe that we are pursuing individual development and fulfillment through buying goods, while failing to do anything about the experience of work that has denied us satisfaction in the first place. ${ }^{201}$ The emphasis that consumer culture places on the pursuit of private, individual solutions, rather than on collective change, cultivates a certain passivity in the people under its sway. ${ }^{202}$

The redesign of store facades and interiors focused attention on the pervasive field of action available to the intelligent seller, on the lure of well-displayed objects and their aesthetic properties. Buying was now more than merely a survey of luxurious objects; it was a total experience in which the retailer became a subtle adviser on personal taste, a joiner who fit individual temperament with proper merchandise.

Neil Harris, The Drama of Consumer Desire, in Cultural Excursion: MaRketing APpetTtes AND Cultural TASTES IN MOdern AMERICA 174, 184-85 (1990). Similarly, shopping mall owners today want nothing to interfere with the "cocooning" of their patrons. See William Glaberson, Swaddling Shoppers: A Mall's Cocoon Effect, N.Y. TrMes, Apr. 21, 1992, at A10.

199. EwEN, supra note 100, at 79. Ewen describes style as follows:

In the marketing of style, in its images, surfaces, and scents, the dream of identity is paraded before our eye's mind. It is not only a dream of public identity, but it also plumbs the wells of inner identity. Style, in its images and objects, offers a provocative typology of needs, a symbolic politics of transcendence. In this sense, style provides people with a powerful means of expression.

Id. at 106. For a fuller account, see Stuart Ewen, Advertising and the Development of Consumer Society, in Cultural Politics in Contemporary America 82 (Ian Angus \& Sut Jhally eds., 1989); see also Nicholas XENOS, SCARCITY AND MODERNITY 100-08 (1989) (describing a "consumption code of the upper-middle-class lifestyle" that seems to pervade the New York Times).

200. See Sut Jhally, Advertising as Religion: The Dialectic of Technology and Magic, in CuL-

TURAL POLITICS IN CONTEMPORARY AMERICA, supra note 199, at 217, 221-22.

201. For example, Lears explains how consumer culture affects our views of our bodies: Clearly, there are some ways in which we probably are more at home in our bodies than our great-grandparents were. But the symbolic universe of advertising is less concerned with solitary pleasures than social relations in private and public. And the persistence of the motif of control down to the present, in ads for everything from hair spray to computers, suggests the continuation of the patterns described here. As the public world outside the self becomes diffuse, distant, governed by institutions we cannot control or even infiuence, the body remains important as an arena we actually can control-or think we can. It becomes a domain of self-expression, a field for developing one's own set of cultural meanings, and a source, quite naturally, of anxiety.

T.J. Jackson Lears, American Advertising and the Reconstruction of the Body, 1880-1930, in FIrNEsS in AMerican Culture: IMAges OF Health, SPORT, AND tHE BoDy, 1830-1940, at 47, 62 (Kathryn Grover ed., 1989).

202. Even apologists for consumer culture can be surprisingly explicit about the passivity and lack of knowledge that underlie it. See, e.g., Robert B. Setrte \& Pamela L. Alreck, Why THEY BUY: AMERICAN CONSUMERS INSIDE AND OUT 280-81 (1986) (applauding advertisement for 
Thus, Radin's focus on the permissibility of buying and selling goods leads us astray in our understanding of commodification. First, Radin understates the pervasiveness of commodification in work. The fact that the fruits of production are for sale is not the only source of commodification. A more significant source is a process of production that systematically strips people of any semblance of control, creativity, and self-fulfillment in work. This means that work is still commodified in a key sense even when there are limits on the market transfer of labor; indeed, the complete ban of labor markets (as in the Soviet model) does not entirely decommodify work. ${ }^{203}$

Second, Radin's emphasis on the role of market transfers causes her to underestimate the extent of commodification of women and their domestic role. Currently, Radin states, the "homemaker services of a wife" are "noncommodified," by which she means that such services are "nonmarketized" (i.e., rendered without the payment of money). ${ }^{204}$ However, the creation of the family as a private refuge, with women relegated to the home, was an integral part of the degradation of work and the corresponding rise of consumer culture.205 Women's unpaid domestic labor is thus commodified in its origin. It is also commodified in its relationship to consumer culture. Homemaker services are performed with the aid of commodities, and homemakers are frequently the targeted audience for advertising promoting those commodities. ${ }^{206}$ In short, although it is not bought and sold, women's unpaid domestic labor is deeply entrenched in the entire system of commodity production.

Finally, the focus on market transfers misleads us concerning the extent of commodification of the body and sexuality. Radin's observation that a full-fledged, open market in sexual services would change our conception of sexuality is true to some extent. But, by asking what would happen if sex were "fully and openly commodified," we see most starkly the danger of an implicit (and inadvertent) approval of the status quo. Asking that question virtually invites us to overlook an important fact: Even if sex is not fully commodified (and never could be), our present society makes a good try at it.

Consumer culture profoundly affects the way we conceive of our bodies

beer directed at young, mostly male consumers ("emulators"): "One's brand of beer has essentially nothing to do with one's academic or professional life, but emulators won't know that!").

203. Similarly, it is not the simple fact that workers do not have title to the product of their labors that renders attainment of a healthy personhood problematic. Vesting title in the workers through employee stock ownership plans ("ESOPs"), for example, would have little bearing on the question of alienation, because ESOPs do not give workers control over management decisions-let alone do anything to break down the separation between conception and execution that necessitates a separate management function in the first place. See, e.g., Henry Hansmann, When Does Worker Ownership Work? ESOPs, Law Firms, Codetermination, and Economic Democracy, 99 YALE L.J. 1749, 1797-1800 (1990).

204. Radin, Market-Inalienability, supra note 9, at 1923 n.260.

205. See Schnably, supra note 99 , at 769-71.

206. See id. at 859-60; see also WRIGHT, supra note 101, at 208 (discussing reinforcement of gender roles by advertising); Elizabeth Mensch \& Alan Freeman, Efficiency and Image: Advertising as an Antitrust Issue, 1990 DuKE L.J. 321, 359-63 (also discussing gender-reinforcing advertising). 
and sexuality. Although we tend to think of our bodies as quintessentially personal, self-image becomes enmeshed in the larger system of commodification. This happens not because we buy and sell our bodies, but because we come to view them in the same terms of display and competition that we apply to the goods and services through which we are constantly invited to recreate ourselves. ${ }^{207}$

With sexuality already "spread . . . like butter on all . . . [consumer] products," 208 it could not be much more commodified. The most important factor promoting the commodification of sexuality is not the extent to which sexual services are bought and sold through prostitution, but the way in which the whole system of consumer culture defines our very conception of ourselves and our sexuality. A focus on legal rules diverts our attention from what is most central to the process of commodification.

In sum, in a system of consumer culture, all commodities have implications for personhood: The category of "fungible" property is an empty one. ${ }^{209}$ The whole system of commodities-the kind of personhood it promotes and the ways that it can be resisted-must be considered. In that

207. For example, conceptions of a desirable body have changed over time from corpulence as a symbol of success to a thinner, more "abstract" ideal. EwEN, supra note 100, at 178; see JoAN JACOBS BRUMBERG, FASTING GIRLS: THE EMERgENCE OF ANOREXIA NERVOSA AS A MODERN DISEASE 258-71 (1988); Susan Bordo, Reading the Slender Body, in BoDy/PolITICS: WoMEN AND THE Discourses of SCIENCE 83 (Mary Jacobus, Evelyn Fox Keller \& Sally Shuttleworth eds., 1990). As Ewen notes, the ideals of the consumer culture and "middle-class bodily rhetoric of the 1980s" together "mark a culture in which self-absorbed careerism, conspicuous consumption, and a conception of self as an object of competitive display have fused to become the preponderant symbols of achievement." EwEN, supra, at 194.

Michel Foucault provides insight into how conceptions form. He writes of disciplines or regimes that are comparable to the modern practices that form our conceptions of the body. As Ewen notes:

In the routinization of labor, in the rote teaching of schoolchildren, in the measured strides of fashion models, even in the detailed positional instructions of exercise tapes or sex manuals, Foucault's "well-trained regiments" can be heard marching in the distance.

Against this historical panorama, the monitored, regulated and segmented body ideal goes against its own claims for itself. On the aesthetic plane of the commercial culture this bodily motif suggests self-motivated, individual power. But its historic roots and its method of construction ("bodybuilding") reveal a person who is, to quote Foucault, the "object and target of power." In their aestheticization, the modern structures of power are turned on their heads, posed as symbols of a free individual. In the world of style, where images seem to float, disconnected from the world that produces them, mastery can be confused with obedience.

Ewen, supra, at 196 (footnote omitted) (citing Michel Foucault, Discipline and PUNish: The BIRTH OF THE PRISON 136 (Alan Sheridan trans., 1977)). For a useful discussion of Foucault's theories of power, discourses, and disciplines, see Christopher Tilley \& Michel Foucault, Towards an Archaeology of Archaeology, in READING MATERIAL CULTURE: STRUCTURALISM, HERMENEUTICS AND POST-STRUCTURAIISM 281 (Christopher Tilley ed., 1990).

208. Stephen Heath, The SeXual Fix 149 (1982).

209. Radin thinks otherwise. See note 50 supra and accompanying text. Under a more systematic approach, however, even the status of things like nuts and bolts as commodities is nowhere near as unproblematic as Radin indicates. Radin anticipates this objection, for she goes on to say:

To this the universal noncommodifier would no doubt respond that commodified nuts and bolts are produced by commodified labor, and that prohibiting commodified labor morally matters as much as prohibiting commodified love, friendship, and sexuality. She might further respond that commodification of their labor forces workers to experience only the commodified versions of love, friendship, and sexuality. 
consideration, the legal rules governing market transfer may or may not be important, but they should not be our central focus. We could, in other words, absolutely forbid the sale of body parts, and in the most important sense still have a commodified conception of ourselves.

Resistance to commodification. Although commodification is more pervasive than Radin allows, it is a tendency, not an overwhelming force. Workers have constantly opposed commodification, collectively and individually. Throughout the twentieth century, they have managed to assert some degree of control over the actual processes of work; the successes of unions, however eroded over the last two decades, show that workers have not been transformed into passive objects of power. ${ }^{210}$ Moreover, as macroeconomic policy has come to be viewed as the state's responsibility, economic and investment decisions have become matters for political dispute and thus open to contest on another level. ${ }^{211}$ For these reasons, and only these reasons, work has not been fully dehumanized.

Similarly, consumer culture is not an irresistible juggernaut. First, it is constantly undermined by its contradictory nature. The same degradation

Radin, Market-Inalienability, supra note 9, at 1912 n.231.

I would agree that it is significant that the nuts and bolts have been produced by commodified labor. If Radin means, however, that the harm to the laborers results because they do not set the price of the nuts and bolts, or because they have to worry about the demand for them, then her argument misses the point. I would also agree that prohibiting commodified labor matters as much as prohibiting other forms of commodification. As I have argued, however, Radin does not provide an adequate account of why that is so.

Finally, I would agree that the commodification of labor is part of a system that fosters and promotes "commodified versions of love, friendship, and sexuality." I object, however, to the notion that it forces anyone to experience them as such. Such a view assumes away the possibility of resistance, thus inadvertently glorifying power.

210. See ClAwSON, supra note 187, at 33 ("Workers' activities were not derivative from what capital did: they fundamentally shaped what happened. Indeed, what capital did (specifically including Taylorism and the rise of bureaucracy) is hardly comprehensible except as a response to workers' success in resisting previous capitalist attempts at control."); ZUBOFF, supra note 187, at 31-36 ("The protective response of so many workers to the demands made on their bodies is ... the source of many work procedures that have been formalized and institutionalized in labor contracts and work rules."); cf. Michael Burawoy, Terrains of Contest: Factory and State under Capitalism and Socialism, SocIALIST REv. July-Aug. 1981, at 83, 90-93 (discussing "psychological and other processes through which subordination to capital is secured, the processes through which workers come to comply with and often advance their own dehumanization").

211. See EDWARDS, supra note 187, at 209-13; Schnably, supra note 99, at 868-70. In mentioning this resistance and struggle, I do not seek to evaluate the strength of the forces at play, or their future prospects. If there is a tendency for economic issues to become politicized, and thus potentially subject to democratic control, there are also powerful counter-trends. One such trend is the glorification of the market as a mechanism that functions best without government interference-an ideology that undermines the prospect of democratic control of the economy. Indeed, with the demise of the Eastern bloc and the Soviet Union, the market, largely free from government control, is hailed as a necessary aspect of democracy. See, e.g., Glenn Frankel, 30 Nations Launch Bank to Aid Eastern Europe: Lending to Promote Switch to Free Market, WASH. Post, Apr. 16, 1991, at D1. Behind the phrase "free-market democracy" lies the substantive assertion that the market and democracy go hand in hand. See, e.g., William E. Schmidt, West Sets Up Store and the Russians Are Seduced, N.Y. TIMEs, Sept. 27, 1991, at A4; Craig R. Whitney, Gorbachev Asks British Leader for Economic Aid, N.Y. TIMES, Sept. 2, 1991, at A5. Another counter-trend is the increasingly undemocratic character of political life itself, see Schnably, supra note 31, at 877-78, so that subjecting the economy to greater government control does little to promote democratic governance of the economy. 
of labor at the workplace that gives the personal sphere of consumption much of its allure has also helped undermine people's economic ability to participate in consumer culture. Many people simply do not have the financial means to find satisfaction or style through purchasing goods, or-with family incomes stagnating since the 1970s-they find it increasingly difficult to do so. ${ }^{212}$ Frustrated expectations can be powerful catalysts for questioning and resistance.

Furthermore, struggles against racism and sexism almost inevitably entail some questioning of consumer culture. Indeed, much that is emblematic of consumer culture is riven with racism and sexism. For example, blacks often are excluded in advertising, ${ }^{213}$ and African-Americans of all income classes face widespread discrimination in shopping. ${ }^{214}$ In addition, advertising often degrades women, or reinforces gender roles by depicting women as responsible for the health and welfare of home life. ${ }^{215}$ People's resistance to these forces constitute part of a larger effort to contain and control the effects of consumer culture.

Given these contradictory social trends, people can be as intractable as consumers as they have been as workers by retaining some capacity to strike a critical stance toward consumer culture. Resistance can take the form of myriad individual acts. ${ }^{216}$ For example, although influential, advertising

212. See BenNetT Harrison \& Barry Bluestone, The Great U-Turn: Corporate ReSTRUCTURING AND THE POLARIZING OF AMERICA 109-38 (1988); ANDREW J. WINNICK, TOWARD Two Societies: The Changing Distributions of Income and Wealth Since 1960, at 203-12 (1989); Wallace C. Peterson, The Silent Depression, Challenge, July-Aug. 1991, at 29; Donald L. Barlett \& James B. Steele, Lost in America: The Middle Class Rules Change to Favor Rich, MIAMI Herald, Nov. 17, 1991, at 1A; Peter T. Kilborn, Unions at a Loss to Reverse Falling Fortunes of Workers, N.Y. TIMES, Sept. 2, 1991, at A1.

213. Cf. Ragin v. New York Times Co., 923 F.2d 995 (2d Cir.) (suit charging the New York Times with racial bias for using virtually no black models in its housing advertising), cert. denied, 112 S. Ct. 81 (1991).

214. See, eg., Ayres, supra note 116, at 817; Lena Williams, When Blacks Shop, Bias Often Accompanies Sale, N.Y. TIMES, Apr. 30, 1991, at AI; see also ANDREASEN, supra note 116, at 59$103,151-77$ (describing African-American consumers and their problems, as well as price discrimination in inner cities).

215. See Diane Barthel, Putting on Appearances: Gender and Advertising (1988); Alice E. Courtney \& Thomas W. Whipple, Sex Stereotrying IN AdVertising 3-30 (1983); Carol M. Tucker, Distortions in Advertising: The Trivialization of American Women, 10 Soc. AcTION \& L. 12 (1984).

At the same time, the very effort to meet the new (and often costly) ideals proposed by consumer culture has been one factor drawing women into the workplace. Because of women's identification with the personal sphere, though, anything that seems to draw them into market relations can be seen as posing a special threat to the possibility of intimacy and personal development with which the family has become identified. That, in turn, has helped fuel the whole set of debates over gender roles. The conservative response is to reinforce the division between the market and the family-for example, by discouraging women, whose traditional role as wife and mother is seen as crucial to the family, from entering the labor force. This response overlooks the fact that the market system itself constantly undermines that division.

216. See, e.g., Patricia J. Williams, The Alchemy of Race AND Rights 46 (1991) (recounting that after being excluded from a store on account of her race, the author "typed up ... the story ...., made a big poster of it, put a nice colorful border around it, and, after Benetton's was truly closed, stuck it to their big sweater-filled window"); Isabel Wilkerson, Black Neighborhood Faces White World With Bitterness, N.Y. TIMEs, June 22, 1992, at A1, A12 (describing how one man "stood silently ... a after a white cashier put his nickels and quarters on the counter," and then 
may be met with skepticism. ${ }^{217}$ In addition, one cannot assume that the mass media impose a single reality upon people; to some extent, audiences actively create their own meanings, which can amount to a form of resistance. ${ }^{218}$ Finally, resistance can manifest itself in a demand for goods and services not produced by our society: collective goods, like day care, for example, or a clean environment. 219

In contrast, although Radin's analysis of the self under universal commodification as a collection of severable aspects rather than an integrated, contextualized whole ${ }^{220}$ bears some resemblance to Ewen's, it inadequately addresses the possibility of resistance. At first glance, Radin's discussion of commodification of the body appears to go beyond the legal rules that govern purchase and sale in the market. However, she consistently returns to that definition of commodification.

Consider Radin's analysis of prostitution. In asking what would happen if "sex were fully and openly commodified" by legalizing prostitution, ${ }^{221} \mathrm{Ra}$ din implicitly assumes that a complete commodification of sexuality would be possible. She asserts that if we fully permitted the sale of women's sexual services, a "change would occur in everyone's discourse about sex, and in particular about women's sexuality."222 According to Radin, an open market in sexuality would lead us to value sexuality only as something to be

told the cashier to "give me my money in my hand like I gave it to you"); Williams, supra note 214, at A14 (describing one woman's practice of allowing clerks who have treated her suspiciously because she is black to run her credit card number for approval, after which she "tell[s] them to tear up the sales and credit slips, give[s] them a lecture on racial prejudice, then walk[s] out the door leaving them holding pieces of paper").

217. For an interesting exploration of a consumer-oriented critique of advertising, see Peter Grahame, Criticalness, Pragmatics, and Everyday Life: Consumer Literacy as Critical Practice, in CRITICAl Theory AND PUblic Life 147 (John Forester ed., 1985).

218. See Ien Ang, The Nature of the Audience, in Questioning the Media: A CrITICAL INTRODUCTION 155 (John Downing, Ali Mohammadi \& Annabelle Sreberny-Mohammadi eds., 1990); Lana Rakow, Feminist Perspectives on Popular Culture, in Questioning THE MEDIA: A CRITICAL INTRODUCTION, supra, at 231. Similarly, when people go to shopping malls they do not necessarily engage in the experience the owner has in mind. John Fiske attempts a "postmodern" understanding of resistance to consumer culture in shopping malls through "guerrilla" tactics, ranging from teenagers "hanging out" at the mall with no intention of buying anything, to shoplifting. JOHN FISKE, UNDERSTANDING POPULAR CULTURE 37-39 (1989). The extent to which these tactics have any effect on the system is a more difficult question, but it at least alerts us to the potential for resistance.

219. Of course, these demands are not inherently destabilizing. As public facilities like playgrounds are displaced by privatized ones (at least for middle-class families), see, e.g., Elizabeth Rudulph, Old-Fashioned Play for Pay, TIME, Nov. 4, 1991, at 86, or as formerly private functions like childcare are taken over by corporations, there is potential for the capitalist system to "rationalize" still other areas of life. The day-care chain Kinder-Care, for example, provides standardized day care for what it calls its "units" (children), see Russell Watson, What Price Day Care?, NewsWEEK, Sept. 10, 1984, at 14, while paying low wages to its "teachers," Myron Magnet, What MassProduced Child Care Is Producing, Fortune, Nov. 28, 1983, at 157, 158. Kinder-Care justly earns frequent comparisons with McDonald's and Kentucky Fried Chicken. See, eg., Dean Foust, Kinder-Care May Stick to Its Sitting, Bus. WeEK, July 13, 1987, at 36; Magnet, supra, at 158. There is, however, no a priori reason to suppose that people's demands can always be defiected from something potentially transformative.

220. See Radin, Market-Inalienability, supra note 9, at 1905.

221. Id. at 1922.

222. Id. 
bought and sold. ${ }^{223}$ Perhaps most strikingly, Radin asserts that if a court were to uphold contracts for prostitution, commodification would be "officially imposed." 224 She bases this assertion solely on the fact of judicial enforcement without explaining the nexus between legal rules and people's selfunderstanding. She never analyzes the inability of the law to impose commodification (or decommodification), as evidenced by the existence of a black market for sexual services. Nor does she explain why the intimate sharing of sexuality she takes as the ideal would disappear under a legal regime permitting a market in sexual services.

Radin's analysis of surrogacy similarly equates commodification with the extent to which legal rules permit or prohibit sale of women's "womb services."225 She argues that if women were permitted to sell their gestational capacities, they would be even more commodified than if prostitution were permitted. All their attributes-not just their sexuality-would be treated as commodities: "There is certainly the danger that women's attributes, such as height, eye color, race, intelligence, and athletic ability, will be monetized.... This monetization commodifies women more broadly than merely with respect to their sexual services or reproductive capacity."226 Indeed, children would also be commodified. ${ }^{227}$ Moreover, damage remedies for breach of surrogacy contracts would amount to officially imposed commodification in precisely the same way as would damages for breach of prostitution contracts. 228

To prevent commodification through surrogacy, Radin asserts, society should prohibit sales of gestational services. ${ }^{229}$ An alternative would be to permit incomplete commodification, in which sales are permitted but women are allowed to change their minds. ${ }^{230}$ After considering the problems of the double bind, Radin offers a tempered endorsement of market-inalienability

223. Id. ("It might make the ideal of nonmonetized sharing impossible."). Radin suggests that "the best way to characterize the present situation is to say that women's sexuality is incompletely commodified." Id. at 1923. That conclusion is premised on the fact that prostitution is incompletely permitted by the law-i.e., it is largely (though not universally) outlawed on the books, but in practice is tolerated, at least insofar as men are concerned. Id. at $1921 \mathrm{n} .256$ ("Legalized prostitution has existed in many places, and there has always been a large black market of which everyone is well aware. That those who purchase prostitutes' services are often not prosecuted seems to indicate that commodification of sexuality, at least by the purchasers, is tolerated."). Examples of near-prostitution, such as topless bars, are also relevant to the analysis. See, eg., Nick Ravo, Topless Clubs For a Crowd In Pin Stripes, N.Y. TIMES, Apr. 15, 1992, at C1, C12 (noting that, at Stringfellows, in New York City, a topless "dancer" will strip at a customer's table, or within "touching distance of a customer," for a higher fee).

224. Radin, Market-Inalienability, supra note 9, at 1924 n.261.

225. Id. at 1929.

226. Id. at 1932.

227. Id. at 1933; cf. id. at 1926 (permitting adoption market would commodify babies' personal attributes and might "destroy personhood as we know it").

228. See id. at 1935 n.294.

229. Id. at 1932-33. Giving away those services would be permitted: Market-inalienability is what Radin addresses. See id.

230. Id. at 1934. 


\section{over incomplete commodification. ${ }^{231}$}

For all its richness and insight, Radin's analysis effectively treats people as passive and unresisting objects of power. It discounts the possibility that women who had to pay damages for breaching prostitution contracts ${ }^{232}$ might react with outrage, rather than experience themselves as totally commodified. Similarly, the more generalized problem Radin sees with fully legalizing prostitution-an inexorable "change . . . in everyone's discourse about sex"-is vastly overstated. The fact that women have sought to pressure advertisers into eliminating sexist stereotyping and have attempted to ban pornography (or at least challenge the perception of it as harmless) shows that women can resist the kind of change that Radin foresees. ${ }^{233} \mathrm{Sim}$ ilarly, her assumption that permitting surrogacy arrangements would result in commodification ignores women's capacity to fight the sexist and objectifying tendencies of paid surrogacy. Individual women, for example, have fought to retain children they have borne under surrogacy contracts, and feminist groups have sought to limit or ban the practice. ${ }^{234}$

Of course, I do not claim that the possibility of resistance to commodification would ever justify enforcing contracts for prostitution or surrogacy. Nor do I assert that resistance to commodification will always succeed. My claim is simply that we effectively write out the very possibility of resistance if we focus exclusively on legal rules. The abortion issue illustrates this point. Although anti-abortion statutes clearly are oppressive to women, a full discussion of these statutes and understanding of their meaning for women requires more than that simple observation: We cannot overlook the fact that women, individually and collectively, have always resisted these laws. ${ }^{235}$

Radin's failure to account for people's capacity for resistance and initiative is significant in part because it renders her analysis inaccurate. By portraying people as the passive beneficiaries of state protection of personhood interests or as the defenseless victims of legal regimes that disrespect personhood, Radin's model leaves no room for personal and collective struggle.

231. See id. at 1936 ("In my view, a form of market-inalienability similar to our regime for ordinary adoption will probably be the better nonideal solution.").

232. One might wonder who would ever bring such a cause of action, but if a legalized prostitution industry arose, one could well imagine that courts would be asked to resolve various disputes involving a woman's contractual duty to complete the transaction.

233. For examples and discussions of programs of feminist resistance, see generally ANDREA DWorkin, Pornography: Men Possessing WoMen (1981); Susan Griffin, PORNOGRaPhy AND SilenCE: Culture's Revenge Against NATURe (1981); MACKInNon, FEMinist Theory OF THE STATE, supra note 134; Caryn Jacobs, Patterns of Violence: A Feminist Perspective on the Regulation of Pornography, 7 HARV. WoMEN's L.J. 5 (1984); Sunstein, supra note 134; Eric Hoffman, Comment, Feminism, Pornography, and Law, 133 U. PA. L. REV. 497 (1985); William K. Layman, Note, Violent Pornography and the Obscenity Doctrine: The Road Not Taken, 75 GEo. L.J. 1475 (1987).

234. Consequently, resistance to commodification can take the form of lobbying for laws outlawing the purchase and sale of human beings or their attributes. My point is not that such laws are necessarily irrelevant, but that it is wrong to focus exclusively on them and to ignore their provenance in collective struggles against commodification.

235. See Schnably, supra note 31 , at 907. 
Thus, Radin's view that labor law and rent control statutes represent recognitions of personhood seems disembodied, removed from a history of conflict and strife, and distant from the current ambiguities of co-option and transformation that still mark them. ${ }^{236}$

Perhaps more significantly, Radin's identification of commodification with purchase and sale suggests that the main response to commodification is to disempower people - to change legal rules to strip people of the power, in whole or in part, to make market transfers of the commodified property or aspect. Even when the disempowerment is not as obvious as a ban on sales, the solution to commodification is state intervention in the name of protection, as in labor legislation or landlord-tenant law. However, when we focus instead on struggle and conflict, we see that power is potentially more pervasive than Radin recognizes, and yet more capable of being resisted. This approach would shed light on a variety of issues.

\section{The second heuristic.}

The second heuristic indicates that the tensions in apparent consensus that the first heuristic uncovers as a matter of theory are brought into the open as a matter of fact by actual struggle and conflict. As noted earlier, the first heuristic helps us understand how policies implemented in the name of a seemingly consensual norm actually may worsen social problems. Because any relationship to property is socially mediated, every act of self-assertion concerning property has the potential to escalate into a broader challenge to policies underlying property rules. The second heuristic bids us to scrutinize the political agendas that might make such escalation more likely. As the following discussion of homeless and bodily commodification issues demonstrates, the second heuristic moves legal theorizing away from a conception of people as the passive objects of state power.

How might the law come to protect personhood interests on the part of the homeless? It might grant protection to people who develop a homelike relationship to a particular piece of property. A homeless person, for example, might develop an attachment to a particular library where she passes her time. Or perhaps several homeless people would develop a stake in an abandoned apartment building they took over and repaired. By upholding the right of the homeless person to use the library even when others object to her hygiene, and by permitting squatters to occupy the building they have taken over, the law would be protecting personhood interests.

However, by overlooking the socially mediated nature of any relation to property, an account like this one ignores the activism that might help produce legal recognition of the interest in the first place. While an individual's desire to spend time in a particular library may at first blush seem a matter of purely individual personhood, it is in fact no more an individual battle than was a sitdown protest at a segregated lunch counter in the 1960s a conflict between the personhood of the white proprietor and that of the indi-

236. See notes 158-168 supra and accompanying text. 
vidual protesters. Just as the system of white supremacy demanded that African-Americans accept an inferior place in society, so too the system of inadequate housing and employment we maintain demands that the homeless not intrude too obviously or blatantly into others' lives. Thus, the presence of the homeless in a public library has the potential to escalate into a challenge to the entire system of exclusion and invisibility, just as any defiance of Jim Crow laws constituted a potential challenge to the whole system of segregation. ${ }^{237}$

No legal theory could definitively describe the occasion when such escalations might occur, but a theory could alert us to that potential by pointing out the ways in which contests over property and commodification issues represent efforts to forge a new personhood. Attempts by groups of homeless persons and advocates to occupy vacant buildings provide a good example. Squatters' campaigns may temporarily provide individuals with shelter. But that plainly is not the only or even the central aim of such campaigns. The organizers of virtually every squatter movement make clear that their aim is to draw attention to the existence of unused buildings at a time when some people have no homes. ${ }^{238}$ As with tenants' campaigns for rent control and other related housing campaigns initiated by local activists, a key aim is mobilizing protest and informing the public, which could help build the ba-

237. Examining Bell v. Maryland, 378 U.S. 226 (1964), which concerned a challenge to the prosecution for trespass of African-Americans who had remained at a lunch counter to protest segregation, Radin sees a "standoff" in personhood terms, because the lunch counter "proprietor could argue that she had her personhood bound up with being able to exclude blacks, while the blacks could argue that their personhood is bound up with being served." Radin, Personhood, supra note 16, at 1011. Describing the protesters' aim as "being served," as if they merely wanted lunch, is a remarkably bland way of characterizing the protesters' interest. On the contrary, their interest lay in resisting and undermining the system of legally sanctioned racism that attempted to cast them as inferior human beings. Was not one goal of the civil rights movement to transform the proprietor?

Equally important, by portraying the conflict at issue in Bell as a standoff later resolved only by governmental intervention, Radin implicitly depicts the African-American protesters as disempowered-ironically, at the moment of their courageous self-assertion. Of course, the civil rights movement did not produce merely a standoff that needed to be resolved only by the intervention of the law. Rather, the protesters' direct collective action forced the elites that dominated the federal government to step in and end de jure segregation. See, e.g., STEWART BurNS, Social MoveMENTS OF THE 1960s: SEARCHING FOR DEMOCRACY 155 (1990) ("Massive, sustained protest, almost entirely nonviolent, compelled the government to act."); GERALD N. RoSENBERG, THE Hollow HoPE: CAN CouRTs BRING ABOUt Social ChANGE? 39-169 (1991) (arguing that the civil rights movement, international pressure, economic changes, and related factors had far more effect in ending segregation than did the courts).

238. Similarly, the members of the Community for Creative Non-Violence who asserted a First Amendment right to sleep in Lafayette Park across from the White House (an assertion rejected by the Supreme Court in Clark v. Community for Creative Non-Violence, 468 U.S. 288 (1984)) did so not because they intended to create a homestead in the park, but to underscore the plight of the homeless. See id. at 291-92, 296; see also Stone v. Agnos, 960 F.2d 893, 894, 895 (9th Cir. 1992) (noting that homeless individual who claimed First Amendment right to sleep in San Francisco's Civic Center Plaza considered himself a "spokesman for homeless persons," and argued that his action " 'dramatized' the plight of the homeless"). Likewise, the "Mad Housers" who built wooden huts for the homeless may have had as one aim forcing the city of Chicago to focus attention on the inadequacy of shelters and the lack of housing. See Don Terry, Homeless Prefer Huts to Chicago's Public Housing, N.Y. TIMES, June 13, 1992, at 7. The main effect of building the huts (which the city decided to remove) appears to have been to force the city to find apartments for some of the homeless who had moved into them. 
sis for effective social action on the problem of homelessness. ${ }^{239}$

We ignore this relationship at great cost. As Lucie White has pointed out, "the movement to end 'homelessness' has brought groups such as churches, mental health professionals, and even the construction industry, into coalition among themselves, on behalf of a passive and vulnerable image of the poor."240 Although it produced some important successes in the short run, this disempowering strategy also represented a missed opportunity to attempt to mobilize coalitions among the poor, leaving the homeless vulnerable to a backlash. ${ }^{241}$ Radin's approach can be understood as the theoretical expression of the political strategy that White describes. Under this approach, the homeless' defiance, as well as their self-development through self-empowerment (individual and collective), however localized and seemingly mundane, vanishes as the homeless are transformed into passive beneficiaries of state protection. ${ }^{242}$

Applying the second heuristic to Radin's analysis of commodification of the body is particularly revealing, for that analysis is, in an important respect, markedly different from her analysis of other issues pertaining to property and personhood. Radin's analysis here shows a real awareness that societal circumstances help create the needs and perceived interests that give

239. It follows from this line of analysis that the first heuristic by itself is inadequate. Earlier, I posed the question whether "we" want the homeless to have homes. See text accompanying note 143 supra. The real question, though, ought to be whether the homeless want to have homes. This question can be posed in different contexts. On an individual basis, the answer of many homeless people might be "yes." If my analysis of the ideal of the home is correct, however, collective, empowering action could well lead many homeless people and their allies to question aspects of that ideal. What good would a home in the suburbs be if there are no jobs nearby and inadequate public transportation to reach them? In other words, just as tenant organizing for rent control and related measures can lead to the forging of a community of people " "reborn' in a socially conscious and collective manner," Schuman, supra note 174, at 245 , so too might efforts to organize rather than merely protect the homeless result in a transformation of their conception of the ideal.

240. White, supra note 108 , at 292 ; see id. at 291-94.

241. See id. at 295-96:

The concept skewed social policy away from the broad crisis in housing affordability, without providing substantial relief for those most desperately in need. It reinforced a long tradition in our culture of categorizing the poor, not in order to target social programs to those with the greatest need, but rather, in order to blame poor people for their own destitution. And although "homelessness" sensationalized the shelter crisis, it may have also helped numb the public to an overwhelming problem.

242. Through such means, "interpretive violence" is inflicted on the very subjects of our concern, not intentionally but by "the subtle ways that our own images and concepts of poverty cut against our intentions." Id. at 312. The phenomenon I describe here seemingly is the academic's equivalent of the poverty lawyer's practices that Anthony Alfieri analyzes so incisively. See Anthony V. Alfieri, Reconstructive Poverty Law Practice: Learning Lessons of Client Narrative, 100 YALE L.J. 2107, 2128-29 (1991) (analyzing "subordination" as one form of "interpretive violence," by which "the lawyer objectifies... [the] image [of client dependency and inferiority], transmuting the client into an object, a thing to be handled, manipulated, and remolded"). These practices lead poverty lawyers unintentionally to overlook clients' own accounts of their struggles, exclude them from important strategic decisions, and enforce obedience to the lawyer's "pre-understanding" of client helplessness and dependence. See id. at 2123-25. To counter the interpretive violence of the poverty lawyer, Alfieri proposes several reconstructive practices. Id. at 2131-45. To the extent one can draw parallels between the practice of poverty lawyers and that of academics, the heuristic guides presented here are similar in form and spirit to the reconstructive practices that Alfieri proposes. 
rise to many of the problems relating to commodification of the body. Why, for example, would a woman agree to serve as a surrogate mother? As Radin points out, the surrogate's motivation cannot be understood simply as a desire to help others, for the effects of existing power structures must be accounted for. There is, Radin notes, a problem of "ironic self-deception. Acting in ways that current gender ideology characterizes as empowering might actually be disempowering. Surrogates may feel they are fulfilling their womanhood by producing a baby for someone else, although they may actually be reinforcing oppressive gender roles." ${ }^{243}$ Surrogacy may also reinforce racial inequalities to the extent that its practice reflects an attempt to alleviate a "shortage" of adoptable white babies. ${ }^{244}$

Furthermore, decisions to sell one's organs-or one's baby, for that matter-cannot be understood apart from their social context. As Radin herself recognizes, only people denied basic material needs would seek to sell one of their kidneys. ${ }^{245}$ One might add that the demand for kidney transplants would not be so high if we had an adequate system of health care delivery capable of preventing problems like high blood pressure that lead to kidney failure. 246

Thus, Radin's nonideal evaluation of commodification carefully examines the socially-mediated nature of the decision to sell one's body or sexual or gestational services, ${ }^{247}$ lending her discussion its richness, and avoiding a presentation of people, individually and collectively, as passive objects of state power. If, for example, the alternatives appear to be either to starve or

243. Radin, Market-Inalienability, supra note 9, at 1930.

244. Cf. Tamar Frankel \& Francis H. Miller, The Inapplicability of Market Theory to Adoptions, 67 B.U. L. REV. 99, 99 (1987) (noting that "most couples want healthy, white infants, and those children are in short supply"); Richard A. Posner, The Regulation of the Market in Adoptions, 67 B.U. L. REV. 59, 65 (1987) ("There is no shortage of nonwhite and of handicapped infants, and of any children who are no longer infants, available for adoption. Such children are substitutes for healthy white infants, and the higher the price of the latter, the greater will be the demand for the former.").

Similarly, why would a woman become a prostitute? Any understanding of this decision as a purely individual career choice would be nonsensical. The decision has far more to do with existing structures of class and gender that expose many women to sexual violence from an early age and deny them meaningful opportunities for self-assertion and economic independence. See Evelina Giobbe, Confronting the Liberal Lies About Prostitution, in ATTACK ON FEMINISM, supra note 121, at 67; Radin, Market-Inalienability, supra note 9, at 1916, 1922.

245. Radin, Market Domain, supra note 9, at 169, 181-82, 187-88.

246. See Max Michael III, Slouching Toward Chaos: American Health Policy and the Homeless, in SAFETY NET, supra note 151, at 44, $45-52$ (discussing problems of health care delivery to the poor in the United States).

As with so many American social problems, racism plays a role. See CHARLES J. DougheRTY, AMERICAN HEALTH CARE: REALITIES, RIGHTS, AND Reforms 14 (1988) (arguing that many urban blacks are unable to obtain long-term follow-up care for chronic health problems, which may "help to explain the much higher rate of kidney failure due to uncontrolled hypertension among blacks").

To some extent, the shortage of body organs also reflects racism. See Paul Delaney, Fighting Myths in a Bid to Get Blacks to Consider Transplants, N.Y. TIMEs, Nov. 6, 1991, at C17 (noting hesitancy by some African-Americans to donate organs based on fears that white doctors will refuse to use donated organs for blacks, or will prematurely declare black patients dead to obtain organs for white transplantees).

247. See Radin, Market-Inalienability, supra note 9, at 1921-36. 
to sell one's kidney, then as Radin recognizes, there is an element of choice in an individual's decision to mutilate her body in exchange for money, as well as an element of condescension in the characterization of such a decision as coerced. ${ }^{248}$ Radin also recognizes to some extent the active role that society takes in constructing personhood. ${ }^{249}$

Unfortunately, Radin eviscerates the potential implicit in her limited recognition of individual and collective activism by persisting in her emphasis on consensus, ${ }^{250}$ evidenced in her constant references to what "we" might do about prostitution, surrogacy, and organ sales in light of the basic values she assumes we share. ${ }^{251}$ I do not necessarily object to the use of the word "we"; nor do I claim that Radin is unaware of the complexities that underlie it.252 What is needed, however, is a much fuller exploration of the different political programs that might emerge from contests over what we should do, and how those different programs might relate to the social constitution of personhood.

Consider Radin's rejection of the prophylactic argument that supports the prohibition of sales of body parts, children, sex, or gestational services. As noted, she partly grounds her objection on the double bind that would be created by prohibition of such sales: Forbidding them does nothing to alleviate the poverty that might motivate people to sell personal things in the first place. ${ }^{253}$ Radin concludes that "this aspect of liberal prophylactic pluralism is hypocritical without a large-scale redistribution of wealth and power that seems highly improbable."254

Radin's rejection of the prophylactic argument implicitly assumes that we could ever effortlessly decide to permit such sales in the first place, ${ }^{255}$ as if markets for these goods and services somehow would arise naturally, and society's involvement would be limited to intervention after the fact. This assumption, however, is patently untrue. Even if the rise of flourishing markets in body parts, sex, or surrogacy did not require a prior legal definition of

248. See Radin, Market Domain, supra note 9, at 169 (characterizing the argument for banning kidney sales because poverty coerces poor people into the sales as "cruelly smug"); id. at 182 ("It seems to add insult to injury to ban desperate exchanges by deeming them coerced by terrible circumstances, without changing the circumstances.").

249. See Radin, Market-Inalienability, supra note 9, at 1921-36; id. at 1881-87 (regarding constitutive effect of rhetoric on personhood).

250. See notes 141-157 supra and accompanying text.

251. See Radin, Market Domain, supra note 9, at 165; Radin, Market-Inalienability, supra note 9, at 1921-36.

252. See Radin, Pragmatist, supra note 7, at 1711 ("What leads some pragmatists into complacency and over-respect for the status quo is partly the failure to ask, Who is 'we"? . . [T] [Te mistake [of failing to be critical about what 'we' refers to] is tempting for a pragmatist whose perspective is that of a member of the dominant group, because from that perspective it seems 'the' perspective.").

253. See Radin, Market-Inalienability, supra note 9, at 1910-11.

254. Id. at 1911.

255. The analysis that follows concerns Radin's rejection of the prophylactic argument. Her ultimate position on the various issues related to commodification of the body turns on more than this single question. As I have already noted, however, Radin's other arguments also rest on the same underlying assumption of political passivity. See notes 221-236 supra and accompanying text. 
rights and responsibilities, ${ }^{256}$ there is little doubt that any serious prospect of such markets would generate substantial controversy. ${ }^{257}$ In that event, what sort of political programs might emerge? It is hard to imagine poor people mobilizing for the right to sell their body parts. ${ }^{258}$ No group of poor people acting collectively would be likely to believe that gaining such a right would do anything to lessen their poverty. More likely the poor would move to ban organ sales and demand government action to help alleviate the economic deprivation that leads to contemplation of such desperate measures. Such efforts would require lobbying, at the very least, and possibly even grassroots organizing and coalition-building. Only from these efforts might we begin to see some prospect for the kind of "large-scale redistribution of wealth and power" that would be needed to ease the dilemma of the double bind.

To be sure, people can and should argue about particular political judgments concerning strategies for social change. My claim regarding grassroots organizing in favor of organ sales is only a prediction of what is likely to take place, not an absolute prescription. What is crucial, however, is that we at least think about those political judgments. To put it another way, when Radin states that we should not ban organ sales because it will do nothing to alleviate poverty, she is not being concrete and pragmatic, notwithstanding her assessment. Like those whom she rightly criticizes for simply asserting that such sales are coerced, Radin here betrays a rarified conception of politics, one which assumes that significant political decisions can be made without at least some struggle or conflict. To be truly pragmatic and concrete, we should determine what sorts of political coalitions could be mobilized to address the problem of poverty that gives rise to the issue of organ sales in the first place. ${ }^{259}$ Only by focusing on this question

256. Cf. Michael L. Connell, Why not a market for human organs?, MIAMr HeRALD, Mar. 29, 1992, at 1C (advocating legal recognition and facilitation of market transfers of body organs).

257. Undoubtedly, many people would disapprove of the existence of such a market. $C f$. National Organ Transplant Act, Pub. L. No. 98-507, § 301, 98 Stat. 2339, 2346-47 (1984), amended by Health Omnibus Programs Extension of 1988, Pub. L. No. 100-607, § 407, 102 Stat. 3048, 3116 (codified at 42 U.S.C. \$274e (1988)) (banning organ purchases for transplantation). Prostitution and baby-selling also are generally prohibited (with some exceptions regarding prostitution). See Freeman, supra note 10, at 77-79. Surrogacy has met with a mixed reception. See, e.g., R. Alta Charo, Legislative Approaches to Surrogate Motherhood, in SURrogate Motherhood: Polmincs AND PRIVACY 88 (Larry Gostin ed., 1990). New York recently enacted a statute making surrogacy contracts void and prohibiting brokers' fees for surrogacy. Act of July 17, 1992, ch. 308, 1992 N.Y. Laws 1005.

258. The same observation could be made about baby-selling and prostitution. Granted, there have been some "prostitutes' rights" groups, but, except perhaps in pointing out the dangers prostitutes face and the hypocrisy of enforcement patterns, their impact and following have been negligible. Cf. Jim Nesbitt, Sex with Street Prostitutes Deadly Gamble with AIDS, Hous. CHRoN., Feb. 2, 1992, at A4 (noting lobbying of prostitution rights advocates for legalization and regulation of prostitution).

259. Moreover, the most concrete change that could result would not be the formal institutional approval of certain words on paper-that is, the issuance of a judicial opinion or the passage of a statute-but the bolstering of collective efforts to change society.

While the question of organ sales is not the most politically pressing issue of our times, organ sales will never simply be "permitted"; there undoubtedly would be significant conflict if proponents of organ sales attempted to change the provision in the U.S. Code banning such sales. See note 257 
can a theory of personhood avoid the tendency to drift. ${ }^{260}$

In contrast to organ sales, surrogacy and prostitution are issues that might inspire widespread political organizing. Here, too, a more concrete and practical focus would require us to think about the conflicting social visions that account for different political responses to surrogacy and prostitution, ${ }^{261}$ for these issues form an arena in which people attempt to constitute gender roles and the family in different ways.

These differences in perspective have disparate implications for some of the double bind and transition problems associated with debates over surrogacy and prostitution. For feminists concerned with dismantling structures of gender inequality, the possibility of "ironic self-deception" that Radin highlights is a major danger of surrogacy. ${ }^{262}$ Becoming a surrogate might seem to represent the exercise of women's power to decide for themselves what is most fulfilling, but surrogacy may at the same time reinforce the oppressive conception that it is women's "essential nature" to be mothers and homemakers. ${ }^{263}$ It is also unclear whether surrogacy would provide economic gain for poor women or simply constitute a new form of exploitation. In addition, feminists would be concerned that outlawing prostitution can be seen as depriving women of a choice of a profession, ${ }^{264}$ whereas permitting it allows men to treat women purely as objects of sexual desire.

Looking at these same issues from a traditionalist perspective, however, we see a very different set of concerns. A major goal from this perspective would be the preservation of traditional gender roles and family structures. The traditionalists' concern over prostitution is obvious: They disapprove of prostitution because it represents a separation of sexuality from marriage and family. Their concern about surrogacy would be that allowing women to bargain over reproduction might undermine their roles as wives and mothers.

The differing goals of feminists and traditionalists point to correspondingly different political programs for dealing with surrogacy and prostitution. For feminist groups, any political program dealing with these issues must include mobilization for broader reforms like comparable worth, abortion rights, and adequate day care, all of which would help free women from the constraints imposed by gender role norms. But as we have seen in recent years, women can also mobilize around curtailment or destruction of abor-

supra. In that context, the question becomes, concretely and practically, how people concerned about poverty might best expend their political energies to do something about it.

260. See notes 166-168 supra and accompanying text.

261. See notes 112-122 supra and accompanying text.

262. See text accompanying note 243 supra.

263. See Radin, Market-Inalienability, supra note 9, at 1929-30; cf. Alessandra Stanley, Marilyn Quayle Says the 1960's Had a Flip Side, N.Y. TIMEs, Aug. 20, 1992, at A10 (quoting speech given by Marilyn Quayle at the Republican National Convention) ("[M]ost women do not wish to be liberated from their essential natures as women.").

264. See Freeman, supra note 10, at 83-85 (relating arguments of some prostitutes' rights groups for legalizing prostitution). 
tion rights and support for a version of the traditional family. ${ }^{265}$

Each of these programs would help forge a very different political consciousness-and create a very different personhood-for many women. For example, the more that women achieved substantive equality, the less concern feminists might have that permitting women to choose surrogacy would entangle them in "ironic self-deception." On the other hand, the more that the traditionalist program succeeded, the more reason we would have to believe that a woman choosing surrogacy would do so precisely as an instantiation of traditional gender role norms. In both cases, the legal regime would be the same- "commodification" would be permitted. In both cases, the double bind would be less troubling, though for very different reasons. But the meaning of surrogacy for most women could hardly be more different: a rejection of confinement to traditional roles in the one case, and confirmation of women's "essential nature" in the other.

It is obvious, then, not only that people struggle to constitute personhood, but that they do so with very different visions in mind. We must choose between them, but that choice can only be made in the actual contests for power that make up social and political life. By posing the question in terms of what legal rules concerning commodification an apolitical "we" should adopt, Radin overlooks the painful but potentially liberating insight that we are as divided as we are united on fundamental issues; and it is but one step beyond that oversight to a theoretical approach that erases the conflicting self-assertions that constitute politics.

\section{Conclusion}

As I noted in the Introduction, one can view Radin's attempt to develop a pragmatic approach to the law as both an effort to find some moderate ground between formalism and full acceptance of the indeterminacy critique, and as a response to the turn away from grand theory. I have argued that, for all their depth and critical acumen, Radin's efforts display an implicit conservative bias. It would be wise to ask whether this bias is a feature of pragmatism itself.

One possible answer is that pragmatism must tend to be conservative because it looks to existing social context and practices as a source of meaning for words and rules, giving it an inherent bias toward the status quo. But this answer seems unconvincing for the simple reason that conflict characterizes our basic values as much as consensus; resistance to the status quo is as much a part of social practice as is support for it. There seems to be no intrinsic reason why a focus on social context and practices should produce a bias toward the existing social order.

We might, then, attribute the implicit conservatism in Radin's work not

265. I do not mean to argue that only conservative women support such programs. My point is simply that women have been active in these controversies, and not all of them in support of feminist causes. See generally Celeste Michelle Condr, Decoding ABortion RHEToRic: Communicating Social Change (1990). 
to pragmatism as such but to a failure to be thoroughly pragmatic. A striking feature of Radin's work is the different treatment she accords human flourishing and nonideal evaluation. Her analysis is relatively pragmatic with respect to transition problems and double binds, in the sense that it is characterized by a close analysis of their social context. But her approach seems decidedly unpragmatic as well. Radin is as abstract as one could possibly be in her broad assertions of deeply embedded values like personal embodiment in the home that, in her view, constitute the ideal of human flourishing. This abstractness brings Radin very close in practice to using the "power-free language" that she has recognized to be illusory. ${ }^{266}$ Ironically, she maintains a high level of abstraction in spite of her asserted commitment to deal with immanent social values rather than some transcendent theory of what is right or good. ${ }^{267}$

Radin also betrays a lack of pragmatism in her failure to deal with conflict and struggle. Notwithstanding her commitment to resolving the subject-object dichotomy in the realm of values, Radin, like many other legal theorists, often treats people like objects devoid of any capacity to participate in a struggle-however unfair, and unequal it may be-to determine their own fates. ${ }^{268}$ This tendency can be thought of as a failure of pragmatism: Close attention to social context, to the innumerable and detailed ways in which people interact, should bring to the forefront people's efforts to determine their own fates.

These shortcomings may result from a tendency to underestimate the need for theoretical and descriptive ambition. As noted earlier, significant elements of the legal academy have increasingly turned away from an abstract or all-encompassing grand theory. Much can be said for that development, particularly insofar as it reflects a decision to focus on the concrete situations of people's lives. But as Steven Smith has suggested in his analysis of pragmatism, there is one respect in which we need greater theoretical ambition, not less. Legal pragmatism can too easily fall into a vacuous neutrality:

The underlying instinct-one that avoids making difficult and controversial substantive judgments upon fundamental human questions-seems very much the same [as the quest for neutrality]. After all, what could be safer and less likely to give offense than a legal philosophy that principally offers innocuous advice such as "Respect human experience," "Listen to all sides," and "Be sensitive to context?"269

Radin's insight and theoretical activity certainly raise her work far above

266. See Radin \& Michelman, Critical Legal Practice, supra note 7, at 1027.

267. See notes 38-39 supra and accompanying text.

268. See Schnably, supra note 31 , at 861 .

269. Smith, supra note 1, at 448; see also David Luban, Legal Traditionalism, 43 STAN. L. REV. 1035, 1040, 1060 (1991) (noting a "backlash against philosophy, and more generally against "fancy theory," " but arguing that the backlash fits uncomfortably well with irrationalism); Steven Walt, Some Problems of Pragmatic Jurisprudence, 70 TEx. L. REv. 317, 324 (1991) (reviewing PosNER, supra note 12) (arguing that "a pragmatic jurisprudence is banal: either its injunctions are components of any plausible jurisprudential theory or its injunctions are uninformative"). 
such banality, but it nonetheless manifests a conspicuous tendency to invoke consensus and intuitive norms, drawing back from "difficult and controversial substantive judgments upon fundamental human questions." My criticism is not, I should add, that Radin fails to resolve these questions but that her approach consistently obscures rather than highlights them.

Radin's tendency to overlook conflict may be understood somewhat through an examination of her more jurisprudentially oriented work. As noted, Radin's desire to preserve the possibility of the rule of law leads her to search for areas of agreement and consensus that can be used as a basis for imposing rules upon people. Although this effort yields some benefits, it does not warrant the blunting of critical awareness that it appears to entail.

How might we avoid this shortcoming? Two approaches merit some consideration. First, we might abandon the notion of the rule of law itself. Radin rejects this approach because she finds the rule of law crucial to her judgment of who we are as a society: "We will still find it deeply normatively appealing to conceive of ourselves as a people governed by its law rather than by arbitrary individual power, because conceiving of ourselves this way I take to be constitutive of ourselves as a political community."270 To some extent this view begs the question of whether we consciously ought to work toward some other self-definition; indeed, Radin herself hints at this possibility, suggesting that her own allegiance, at least to the phrase "the rule of law," is not unqualified.271 Still, rejecting the ideal of the rule of law seems unrealistic and even misguided. Particularly at a time when Eastern Europe and the former Soviet republics are attempting to free themselves from a heritage of arbitrary rule, we might pause before we dismiss the power of the ideal too quickly. ${ }^{272}$

Instead, I would advocate another, seemingly more modest approach that may also be the more powerful one in the long run: We should rethink what it means to be an interpretive community. This approach allows us to address directly the weaknesses in Radin's work. The first is a tendency to focus too exclusively on legal rules. 273 To the extent that Radin's approach suggests that legal texts and judicial decisions are the focus of our collective self-constitution, that focus is not only inaccurate but also potentially disempowering. ${ }^{274}$ Christopher Tomlins' conclusion about the significance of labor law could well be generalized: "[A] counterfeit liberty is the most that

270. Radin, Rule of Law, supra note 3, at 813.

271. Radin discusses the problems with the phrase:

Whether or not the term "the Rule of Law" should be dropped becomes another pragmatic question, a matter of judgment about its ideological baggage. Is the term indelibly linked in our usage with the ideas that law is instrumental and consists of pre-existing formal rules applied in a value-free manner? Or can its precepts be reinterpreted in the way I have Id. at 819 . begun to suggest?

272. Cf. E.P. Thompson, Whigs and Hunters: The Origin of the Black ACT 267 (1975) ("[I]f the actuality of the law's operation in class-divided societies has, again and again, fallen short of its own rhetoric of equity, yet the notion of the rule of law is itself an unqualified good.").

273. See notes 158-179 supra and accompanying text.

274. See notes 158-179 supra and accompanying text; Schnably, supra note 31, at 872-73. 
American workers and their organizations have been able to gain through the state. Its reality they must create for themselves."275

The second weakness is Radin's assumption that when we look to forms of social life to give meaning to norms, "community" necessarily means consensus, at least in some respects. ${ }^{276}$ At a high level of generality, the assumption that there are some shared values may be right, but as a practical matter, it is far easier to overestimate, rather than underestimate, the importance of that observation. I would readily concede that if we shared absolutely nothing in common, communicative conflict and tension would be impossible: We would simply be talking past each other. But the more interesting focus of attention for legal scholars, at least now, may well be the differing social visions that we bring to the disputes that divide our communities. ${ }^{277}$ Of course, one might ask what we hope to accomplish by a shift in the focus of legal scholarship. My answer, admittedly incomplete, is that it would at least illuminate the issues more fully, and counter what I believe is a tendency on the part of much current legal theory to understate both the extent to which people are oppressed by the law and the degree to which they shape it through their struggles. Contest, discord, conflicting self-assertion-these are what we ought to think of first when we talk about community, even if they do not tell the whole story.

275. TomLINS, supra note 163 , at 328.

276. Radin argues that social life gives meaning to our Constitution and other premises: The Constitution, for example, because it "constitutes" the polity, consists of more than the words on the document. The words would be meaningless without everything else in our moral/political culture that gives them their constitutive meaning. Some of the other things that make the Constitution what it is can be other written texts, like the Declaration of Independence, but some are unwritten basic premises of our moral and political world, like the principle of one person, one vote. Our other important documents and our unwritten basic premises all take meaning from the way we understand (and continue to reconstruct) the historical events surrounding the Founding and other salient points in our history. Statutes, regulations, and other common-sense legal artifacts are not authoritative in some way separable from their meaning, and their meaning is dependent on their entire social context.

Radin, supra note 8, at 265.

277. With regard to abortion, for example, the indeterminacy critique of "pro-life" and "prochoice" arguments seems correct. That is, any argument about when human life begins, or about what the scope of privacy should be, will prove fundamentally contradictory. See Schnably, supra note 99, at 724-61, 782-816. In turn, those differing social visions are grounded in social and political contests over the sort of personhood-as women and men-we will create as a society. Id. at 830-84. Precisely by looking to what most divides us on abortion, rather than looking to values we allegedly share at some high level of generality, will we most shed light on the abortion issue. 